\title{
Immigration, Race, and Political Polarization
}

\author{
Michael Hout and Christopher Maggio
}

\begin{abstract}
The growth of non-White immigration in the post-1965 era has been a major force in defining the relationship between race and immigration in the contemporary United States. Another key trend, political polarization, has been important in understanding this relationship, exemplified most recently by the election of the strongly anti-immigrant and racially inflammatory presidential candidate, Donald Trump. This article explores the contemporary relationship between race, immigration, and political polarization by analyzing several key components of said relationship. Echoing past research, we find that racial and immigration attitudes are increasingly split along political party lines. We also show that, although the positive correlation between racial resentment and restrictive immigration attitudes has generally increased in recent times, 2016 saw an uptick in this correlation, a finding that is likely related to the mobilization of these issues in 2016. Again paralleling prior research, we show that both conservative racial attitudes and restrictive immigration attitudes were strong predictors of Trump voting among nonHispanic Whites, both in the general and primary elections, and even controlling for voting patterns in the 2012 general election, highlighting the unique connection between Trump and these issues. Overall, these findings point toward an increased importance of race and immigration in the current political climate.
\end{abstract}

Both authors contributed equally to the article; order of authorship is alphabetical.

Michael Hout is a professor of sociology at New York University.

Christopher Maggio is a Ph.D. candidate in sociology at the Graduate Center, City University of New York. 


\section{Introduction}

The post-1965 era in the United States has brought a large wave of non-White immigration. The growth of Asian immigration in the 1800s and early 1900s was cut short by restrictive policies (Lee 2002; Ngai 1999), and despite a long history of Mexican migration (Henderson 2011), contemporary patterns overwhelm historical numbers, particularly in relation to long-term settlement (Migration Policy Institute 2019). This is not to mention movement from other Latin American countries, or growing Black migration from Africa and the Caribbean, which cannot help but raise questions of the position of these groups in relation to African-Americans with a longer history of U.S. ancestry (Waters 1994; Hamilton 2019).

Although race and immigration have always been interlinked, and have long been central to American political divisions, the demographic trends described above have made the connection between the two topics very pertinent today. Moreover, both topics and their intersection are important to gaining insight into what some have described as a historically unique era of political polarization (see Baldassarri and Park (2020) for a nuanced analysis of this topic). To that end, this article examines some of the key issues surrounding race, immigration, and political polarization in the contemporary United States. First, where do racial and immigration attitudes sit in terms of trends in party polarization, and how has the relationship between racial and immigration attitudes evolved in recent decades? How does the recent election of Donald Trump, a candidate who has upended much about the political status quo around race and immigration, fit into this story? 
Using various datasets, we attempt to provide answers to these questions, some of which support or compliment prior research, others of which are more novel. Firstly, as anticipated, we demonstrate the divergence between Democrats and Republicans in terms of racial and immigration attitudes in recent times, with a strong trend toward more liberal views among Democrats and less change among Republicans. Interestingly, Independents also became more liberal on both issues. Additionally, we demonstrate that the positive correlation between racial resentment and restrictive attitudes on immigration among Whites mostly increased in recent times, but ticked up even more in 2016, a change likely tied to the Trump phenomenon. Further inspection reveals that these patterns were clearest among White Democrats. What follows provides some background on the relationship between race, immigration, and polarization in the historical and contemporary United States, a summary of our data and methodology, a more detailed presentation of the results mentioned above, as well as our conclusions.

\section{Background}

Race has long been intertwined with immigration in the United States and is a key factor in understanding both historical immigration policies and attitudes. Race long informed who could and could not naturalize; racial qualifications for naturalization were not fully eliminated until 1952 (Lopez 1997). The Chinese Exclusion Act of 1882 further tied U.S. immigration policy to race and ethnicity (Lee 2002). The National Origins Act of 1924 broadened racial exclusion (Ngai 1999). Immigrants from Ireland and South, Central, and Eastern Europe were understood in a racialized manner before being fully recognized as White (Roediger 2005), although clearly not as distinctly as Asians and Blacks (Lieberson 1982). The Immigration and Nationality Act of 1965 aimed, at least in 
part, to remove race and nationality considerations from immigration policy (Chin 1996).

For this reason and others (Massey and Pren 2012), the post-1965 era has seen a sustained growth of non-White immigration, drastically altering the racial demography of the country. Mexico has been by far the largest contributor to this wave, but countries from other parts of Latin America, the Caribbean, Asia, Africa, and the Middle East have each contributed as well. The fact that recent immigration has included so many nonWhite groups cannot be ignored when considering the contemporary relationship between racial and immigration attitudes, though history shows clearly how almost any difference can become racialized.

Studying survey data since 1992, Miller (2018) found that racial resentment was a much more important predictor of restrictive immigration attitudes than any economic factors. Other research has found that related concepts such as ethnocentrism and stereotypical thinking are routinely good predictors of resistance to immigration (see Hainmueller and Hopkins (2014) for a literature review). There also appear to be racebased preferences for particular immigrant groups over others, with a recent survey showing that Americans prefer European and Asian immigrants over African, Latin American and Middle Eastern immigrants (in this order) (Pew Research Center 2015). While preferences for "high-skill" immigration (Hainmueller and Hiscox 2010; Hainmueller, Hiscox, and Margalit 2015) may play a role in the relatively low rating of Latin American immigrants, this is less likely to explain the attitudes toward African and Middle Eastern immigrants, who tend to have higher levels of education than Mexican or Central American migrants, for instance (Krogstad and Radford 2018). Additionally, 
Newman and Malhotra (2019) demonstrate through several different analyses the various ways in which the preference for "high-skill" immigrants is likely not race neutral.

Although Alba (2018) showed the weak points in projections of a majorityminority U.S.A., many Whites express anxieties with codewords like "replacement" and with more benign expressions. A literature examining how Whites react to this potentiality has emerged, with backlash manifesting in more conservative positions in terms of racial attitudes and political ideology (Craig, Rucker, and Richeson 2018), though some ways of framing demographic change can potentially mitigate this backlash (Myers and Levy 2018). Local demographic changes combined with increased salience of immigration in the media can prime resistance to immigration (Hopkins 2010). The tendency is also strong in "new destinations" (Massey 2008), that is, in places with little pre-existing non-White immigration (Newman 2013). ${ }^{1}$ Such local demographic changes were perhaps important for Trump support as well (Newman, Shah, and Collingwood 2018; Enos 2017), but it is not clear that immigration has had a more generally conservatizing impact on American politics (Mayda, Peri, and Steingress 2018). Regardless, while both racial and immigration attitudes have long been important political factors, the importance of these factors was likely heightened in 2016, as demonstrated by previous research (Sides 2017; Reny, Collingwood, and Valenzuela 2019), as well as our findings below. For the issue of immigration, the perceived gulf between Clinton and Trump seems to have played an important role (Mutz 2018).

Across all of the time periods described above, racial and immigration attitudes have been divided across various affiliations. Business interests have often supported

\footnotetext{
${ }^{1}$ Again, however, it is important to remember that the reaction to different immigrantorigin groups is likely not the same (Ha 2010).
} 
immigration as a way to secure low wage or "high-skilled" labor (Higham 1955; Martin, Lowell, and Martin 2001). Regional divides have of course been important in understanding divergent racial attitudes (Quillian 1996), but underestimating the extent of racism outside of the South has always been a mistake (Lieberson 1982; Rieder 1985). Whites tend to resist immigration more than other racial groups do (Pew Research Center 2017), but Marrow (2011) highlighted evidence of immigration backlash among African Americans. While both major political parties have demonstrated a propensity to pursue policies that can be viewed as conservative with respect to race and/or immigration in recent decades (Street, Zepeda-Millán, and Jones-Correa 2015; Pierce 2019; Ahmadi 2011; Wheelock and Hartmann 2007), the research presented below as well as other scholarship has shown an increasing Democratic-Republican divide on immigration and racial attitudes (Jones 2019; Pew Research Center 2017).

\section{Data $^{2}$}

We use several data sets in this study. First, to examine trends in racial and immigration attitudes from 1994 to 2018, specifically by political party identification, we use the General Social Survey (GSS), a public opinion survey with 13,182 respondents and 9,255 non-Hispanic White respondents in this time period that provided relevant information for the racial attitude and immigration preference questions. Then, to examine the correlation between racial resentment and immigration attitudes across time (1992-2016), we use the American National Election Study (ANES). This study is a voting and public opinion survey, with 11,527 non-Hispanic Whites who have provided

\footnotetext{
${ }^{2}$ The variables studied in this article are not necessarily available for all years, and the analyses below will reflect this. Additionally, the wording of certain questions has changed slightly over time.
} 
relevant answers to the racial resentment and immigration preference questions, from 1992 to 2016. As a robustness check on the results here, we again analyze the GSS, as well as the Cooperative Congressional Election Study (CCES) for 2016, another voting and public opinion survey. The CCES has a sample of 38,967 non-Hispanic Whites who have provided relevant answers to the racial and immigration questions, and is merged with the 2010-2014 American Community Survey (ACS) for multivariate analysis. ${ }^{3}$ Lastly, we again use the CCES to study the relationship between Trump voting in 2016 and racial attitudes/immigration policy attitudes, merging in Election $\mathrm{Atlas}^{4}$ data from 2012 and the 2010-2014 ACS.

\section{Methodology $y^{5}$}

Using the GSS, we demonstrate how the racial and immigration attitudes of various respondents have changed from 1994 to 2018. Generally speaking, racial resentment measures have been intended to, in the post-Jim Crow era, capture less overt racism, characterized by "antagonism to political demands by blacks, rejection of the assumption that real discriminatory barriers impede black advancement, and hostility to any favor or benefit blacks might now receive from government" (Bobo et al. 2012, 60; Kinder and Sears 1981; Kinder and Sanders 1996). From the GSS, we generate a racial resentment scale ${ }^{6}$ using three variables:

\footnotetext{
${ }^{3}$ The county-level ACS data is compiled by Social Explorer (https://www.socialexplorer.com/).

${ }^{4}$ https://uselectionatlas.org/

5 Any answers like "don't know" or "no answer" are excluded from the options presented below. The phrasing of certain questions varies slightly depending on the year of the survey.

${ }^{6}$ The construction strategy for the scales in this study differs depending on the scale.
} 
- "Do you agree strongly, agree somewhat, neither agree nor disagree, disagree somewhat, or disagree strongly with the following statement: Irish, Italians, Jewish and many other minorities overcame prejudice and worked their way up. Blacks should do the same without special favors."

- "On the average Blacks have worse jobs, income, and housing than white people. Do you think these differences are...

○ Mainly due to discrimination?"

- "On the average Blacks have worse jobs, income, and housing than white people. Do you think these differences are...

- Because most Blacks just don't have the motivation or will power to pull themselves up out of poverty?"

This variable and all racial and immigration attitude variables are coded so that higher numbers equate to more conservative racial and immigration attitudes. For immigration policy preferences we examine responses to the following question:

- "Do you think the number of immigrants to America nowadays should be...

- Increased a lot

- Increased a little

- Remain the same as it is

- Reduced a little

○ Reduced a lot?"

For the descriptive analyses, this question is re-coded so that "increased" is one category, "reduced" is one category, and "remain the same as it is now" is excluded. For correlational analyses, this question is left as it is above. 
Using the ANES, we examine how the correlation between racial resentment and immigration preferences has evolved from 1992 to 2016 for non-Hispanic Whites. Specifically, we use a racial resentment scale based on the following questions from the ANES, again with the options "agree strongly, agree somewhat, neither agree nor disagree, disagree somewhat, or disagree strongly":

- "Irish, Italians, Jewish and many other minorities overcame prejudice and worked their way up. Blacks should to the same without any special favors."

- "It's really a matter of some people not trying hard enough; if blacks would only try harder they could be just as well off as whites."

- "Over the past few years blacks have gotten less than they deserve."

- "Generations of slavery and discrimination have created conditions that make it difficult for blacks to work their way out of the lower class."

To measure immigration preferences, we use the following question:

- "Do you think the number of immigrants from foreign countries who are permitted to come to the United States to live should be...

○ Increased a lot

○ Increased a little

○ Be the same as now

- Decreased a little

- Decreased a lot"

We test the robustness of this relationship first using the GSS, then incorporating a new scale measure of racial attitudes from the 2016 CCES. This survey offers a battery 
of racial attitude questions that provide different features from the measures described above, again with a five-point agreement scale:

- "I often find myself fearful of people of other races."

- "White people in the U.S. have certain advantages because of the color of their skin.”

- "Racial problems in the U.S. are rare, isolated situations."

- "I am angry that racism exists."

These questions provide a more contemporary understanding of racial attitudes meant to account for racial fear, acknowledgement of institutional racism, and racial empathy ("FIRE," DeSante and Smith 2017). By specifically not mentioning African Americans, these measures remove an outdated racial binary, implicitly acknowledging the growing racial diversity in the United States by dropping the Black-White framing. Increasing diversity is, of course, driven by immigration and its follow-on growth of the second generation and beyond, thus making the new measures particularly relevant in examining the relationship between racial attitudes and immigration attitudes. The items have also been shown to be correlated with other racial attitude measures, as well as various important outcomes such as conservative voting and policy positions (DeSante and Smith 2017; 2018; Neville et al. 2000; Green and McElwee 2019).

We test the correlation between this racial attitude scale and an immigration policy attitude scale generated from the following "yes or no" questions in the CCES:

- "What do you think the U.S. government should do about immigration?"

○ "Grant legal status to all illegal immigrants who have held jobs and paid taxes for at least 3 years, and not been convicted of any felony crimes" 
○ "Grant legal status to people who were brought to the U.S. illegally as children, but who have graduated from a U.S. high school"

○ "Increase the number of border patrols on the U.S.-Mexican border"

○ "Identify and deport illegal immigrants"

These questions focus specifically on undocumented immigration and thus provide insight into some of the biggest issues in the immigration debate today, and also help provide a robustness check on other results in this study. In addition to examining the bivariate correlation coefficient for these two scales, we also examine the bivariate regression coefficient, and how this coefficient changes after adding various controls. We first add demographic controls (gender, birth year, children, marital status, and citizenship/immigrant generation), then socioeconomic controls (education, family income, employment status, and union status), contextual controls (county-level nonHispanic White population and logged population density from the 2010-2014 ACS, length of residence in one's current home and city, and state of residence (or Washington, D.C.)), assessments of national and household economic conditions, and finally political ideology. These analyses are also limited to non-Hispanic Whites.

Finally, using logistic regression models, we examine the relationship between Trump voting in 2016 and both racial attitudes and immigration policy attitudes, again using the CCES and scales mentioned above, specifically examining non-Hispanic White U.S. citizens in the general election and Republican primaries. For the general election, we operationalize Trump voting in 3 ways: Trump vs. all other options including nonvoting, Trump vs. all candidates, and Trump vs. Clinton. ${ }^{7}$ For the Republican primaries,

\footnotetext{
${ }^{7}$ Voting data is not available for all respondents.
} 
we operationalize Trump voting as Trump vs. all other candidates. ${ }^{8}$ These models control for various factors mentioned above: gender, birth year, children, marital status, nativity/immigrant generation, education, family income, employment status, union status, county-level non-Hispanic White population and logged population density from the 2010-2014 ACS, length of residence in one's current home and city, state of residence (or Washington, D.C.), assessments of national and household economic conditions, and political ideology. Additionally, these models control for voting patterns in the 2012 general election, both at the individual and county level, in order to determine if racial and immigration attitudes were particularly important for the 2016 election.

\section{Results}

Figure 1 uses the GSS to demonstrate the trend in opinions for increasing or decreasing immigration for all residents, all likely voters (those who said that they voted in the most recent presidential election), and all non-Hispanic White likely voters. Figure 2 demonstrates the trend in preference for a reduction in immigration by political party affiliation for non-Hispanic White likely voters.

\section{Figure 1 here}

Figure 2 here

Notably, a much smaller portion of respondents wanted to reduce immigration in 2018 compared to 1994 , and a larger portion wanted to increase immigration, something

\footnotetext{
${ }^{8}$ For analysis of the Republican primary elections, we include states that hold caucuses, but not states that hold conventions, and not states whose primaries/caucuses were not meaningful to the outcome of the election, those states that held these primaries/caucuses after Trump had, in effect, won the nomination (California, Montana, Nebraska, New Jersey, New Mexico, Oregon, South Dakota, Washington, and West Virginia). In controlling for state of residence, we are able to account for specific features of particular state primaries or caucuses.
} 
very few respondents in 1994 advocated for. While desiring a decrease in immigration was the majority view in 1994, it dipped below 50\% in the mid-2000s (for all residents) and in 2018 was well below that mark, though still higher than the number of respondents who wanted to increase immigration. The overall pattern across this time period is similar for likely voters, as well as White likely voters. Figure 2 shows us that this trend is largely driven by dramatic changes in the attitudes of Democrats and Independents. Republicans saw some liberalization from 1994 to 2000, but have changed their views little since then, and in 2018 were much more conservative on this topic than Democrats and Independents, something that was not so true in 1994.

We see a similar trend for racial resentment (as defined by the scale described above $)^{9}$ for non-Hispanic White likely voters in Figure 3:

\section{Figure 3 here}

While the gap between Republicans and Independents, and particularly Republicans and Democrats, was at least noticeable in 1996, it has widened greatly since then. Again, this is accounted for by liberalization on the part of Democrats, and to a lesser extent Independents, and little movement for Republicans.

The figures described above provide a straightforward summary of how racial and immigration attitudes have played out in the contemporary era of political polarization. Like on many issues (Baldassarri and Park 2020), Democrats and Republicans have diverged. But what about the relationship between racial and immigration attitudes? Has

\footnotetext{
${ }^{9}$ The scale was unintuitive so we used a linear transformation for Figure 3 (New score = $(90 / 6)^{*}$ Old score +50$)$. This transforms -3 into 5 and +3 into 95 , with the other scores evenly spaced in between.
} 
this changed as both racial diversity and the foreign-born population have grown? Figure 4 demonstrates how the correlation between the racial resentment scale and the immigration preference question, both from the ANES, has changed across time, specifically for non-Hispanic Whites:

\section{Figure 4 here}

The positive correlation for each survey year demonstrates that, for non-Hispanic White respondents, higher racial resentment is positively correlated with more restrictive immigration preferences. This begins with a correlation of 0.26 in 1992, and generally shows an increase ${ }^{10}$ across time, reaching 0.37 in 2012, and surging to 0.54 in 2016 . We cannot make a certain claim from this analysis as to the role that the Trump campaign and election played in this surge, but it certainly seems likely that his heightened racial and immigration-related rhetoric is important in its timing. Figure 5 shows a similar pattern for non-Hispanic Whites in the GSS, though it is less clear that the long-term increase in correlation began as far back. Interestingly, the correlation remains high, and even increases, in 2018.

\section{Figure 5 here}

We provide another robustness check on the results from 2016, analyzing the correlation between the new racial attitudes scale (FIRE) and immigration policy preference scale, both from the CCES, again for non-Hispanic Whites. The result is similar to that found in the ANES for 2016. The correlation is actually slightly stronger, approximately 0.59 . This provides further evidence of a particularly strong relationship between racial and immigration attitudes in 2016.

${ }^{10}$ There was a slight decrease in 2008. 
Figures 6 and 7 look at the trends over time for the ANES and GSS by political party identification for non-Hispanic Whites:

\section{Figure 6 here}

Figure 7 here

Figure 6 generally shows that, in the ANES, the correlation between racial resentment and immigration policy attitudes has increased long-term for Democrats, with an uptick in 2016. This is similar in the GSS (Figure 7), though again with less evidence of an increase further back in time, and the uptick remaining for 2018 (the correlation was comparatively high in 2008 as well). For Independents, this correlation shows some evidence of increase over time in the ANES, though not so much in the GSS, again with an uptick more recently for both data sets. However, the uptick for Independents appears to begin in 2014 according to the GSS, prior to the Trump campaign and election (data is not available for 2014 in the ANES). For Republicans, some evidence of an increase over time is only seen in the GSS. This demonstrates that the pattern among non-Hispanic Whites overall is best approximated by the pattern for non-Hispanic White Democrats, likely indicating that they are the most important group in driving said pattern.

Table 1 examines the correlation between racial and immigration attitudes further, looking at the OLS regression coefficient for the racial attitude scale predicting the immigration policy attitude scale in the CCES for non-Hispanic Whites, with and without the controls mentioned above.

\section{Table 1 here}

In the bivariate model ("baseline"), an increase in racial conservatism predicts more restrictive immigration policy attitudes for non-Hispanic Whites (0.59 standard 
deviations). This result is statistically significant, and does not change dramatically after adding demographic, socioeconomic, and contextual controls. There is more of a decline in the magnitude after adding controls for national and household economic assessments (to 0.41 standard deviations). The coefficient decreases further when adding the control for political ideology (to 0.32 standard deviations), but the relationship remains statistically significant. This reveals that some of the correlation between racial attitudes and immigration policy attitudes can be accounted for by controlling for economic assessments and overall political ideology. Regardless, even after controlling for these variables as well as demographic, socioeconomic, and contextual variables, there is a substantial and statistically significant relationship between the two primary variables in Table $1 .{ }^{11}$

On the recommendation of DeSante and Smith (2017), because the FIRE items capture various aspects of racial attitudes (fear, acknowledgement of institutional racism, and empathy), we also examine the relationship between immigration policy attitudes and each item separately, in Table $2^{12}$ :

\section{Table 2 here}

As expected, for each individual question, more conservative racial attitudes predict more conservative immigration policy attitudes, and this holds after adding all controls. In other words, non-Hispanic Whites not acknowledging White advantages, believing racial

\footnotetext{
${ }^{11}$ Poisson models not displayed show similar results.

${ }^{12}$ The sample sizes for Table 2 are lower than for Table 1 because cases with missing values on any of the FIRE items are excluded from Table 2 but not Table 1, where the scale is constructed (as an average) from whatever FIRE items are available (all four items are available in the overwhelming majority of cases). The same can be said for the difference in sample sizes between Table 3 and Table 4.
} 
problems are rare, being less angry about racism, and often fearing other races, are all more likely to hold restrictive immigration policy attitudes.

Now we move on to analyzing the voting patterns of non-Hispanic White U.S. citizens in the 2016 election in Table $3^{13}$ :

\section{Table 3 here}

Table 3 demonstrates that, even controlling for various factors, including voting patterns in the 2012 general election at the individual and county levels, there is a positive relationship between Trump voting and conservative racial attitudes, as well as between Trump voting and conservative immigration attitudes, for non-Hispanic White U.S. citizens, as has been confirmed by prior research. These relationships hold when limiting the sample to the "traditional" swing states, as defined by Silver (2016).

Interestingly, conservative racial and immigration attitudes also positively predict Trump voting in the Republican primaries in 2016, providing more evidence that racial/immigration attitudes are predicting Trump voting specifically, not just Republican support.

Figure 8 graphs Trump voting, in both the general and primary elections of 2016, by those at lower $\left(25^{\text {th }}\right.$ percentile) and higher $\left(75^{\text {th }}\right.$ percentile $)$ levels of racial and immigration conservatism using the "margins" command in Stata to specifically isolate these relationships, controlling for the factors mentioned above:

Figure 8 here

These relationships are quite strong. For the general election, non-Hispanic Whites in the $75^{\text {th }}$ percentile of racially conservative attitudes were 9 percentage points more likely to

\footnotetext{
${ }^{13}$ All below analyses exclude Alaska because the state's 2012 voting results from Election Atlas are not reported by borough, which is its closest equivalent to county.
} 
vote for Trump than those in the $25^{\text {th }}$ percentile. This difference is 7.2 percentage points for the Republican primary. Those non-Hispanic Whites in the $75^{\text {th }}$ percentile of immigration conservatism were 8.9 percentage points more likely to vote for Trump than those in the $25^{\text {th }}$ percentile, while this difference is 12 percentage points for the Republican primaries. Overall, this provides clear evidence of the importance of racial and immigration attitudes when analyzing the 2016 election.

Lastly, again because DeSante and Smith (2017) recommend examining each FIRE item separately, we analyze the relationship between each of these measures and Trump voting in Table 4:

\section{Table 4 here}

Generally speaking, the more conservative racial positions positively predict Trump voting at a statistically significant level. One exception is that often being fearful of other races is not a statistically significant predictor in the models predicting Trump voting vs. Clinton voting, but it is in the other models. The other exception is that, in the Republican primaries, Trump voters were actually less likely to say that racial problems are rare, highlighting the more complicated task of distinguishing Trump support from more general Republican orthodoxy in certain respects.

\section{Conclusion}

This study has highlighted several key aspects of the relationship between race, immigration, and political polarization in recent times. Notably, racial resentment and preferences about the level of immigration have become increasingly polarized along party lines in recent years, with a clear liberalization on these questions among Democrats and Independents, and less change among Republicans. In terms of the 
relationship between racial resentment and restrictive immigration attitudes, we find an increasing positive correlation among non-Hispanic Whites in recent times and, notably, an uptick in 2016 that appears to hold and even increase in 2018, at least according to the GSS. Based on analysis by party affiliation, it appears that White Democrats are likely the most important group in driving this trend. Again, further research will be needed to more deeply understand this pattern, but it is difficult to imagine that growing non-White immigration overall, party polarization on these issues, a growing connection of these issues in the minds of Democrats, and pushback against the mobilization of racial resentment and anti-immigrant attitudes by Trump (and perhaps the Republican Party more generally) do not play a role. The role of Trump, of course, is once again highlighted by the positive relationship between Trump voting among non-Hispanic Whites and racial/immigration conservatism, a relationship that broadly held in the 2016 general and primary elections, even controlling for voting patterns in the 2012 general election.

It should be noted that none of the research presented above tells the entire contemporary story about race, immigration, and political polarization in the United States. Baldassarri and Park (2020) demonstrate that polarization differs depending on whether the outcomes examined are related to moral issues, economic issues, or civil rights issues, with exceptions existing even within these categories. Bobo et al. (2012) demonstrate the nuance in understanding the evolution (or lack thereof) of racial attitudes over time, and caution against generalizing based on a single or even a few measures. Other research has shown large gaps in immigration views depending on which aspect of immigration is being discussed, including impact on the economy, crime, or culture (Pew 
Research Center 2015). Moreover, despite the clear relationship between racial and immigration attitudes described above, more research is necessary to uncover why this relationship has emerged. Non-White immigration to the United States has been increasing for a long time, and in reality has existed for much of U.S. history, yet we do not have reliable survey data on racial and immigration attitudes far enough back in time to truly trace their relationship through the various waves of immigration and across key events. We know without a doubt that race and immigration have been linked throughout U.S. history, but how today's understanding differs from the past will require investment in other methodologies. Lastly, we also know that non-White immigration is spreading to places in the U.S. with little previous history of such trends, leaving important questions: How will racial views be impacted as non-White and non-Black groups become the largest minority, or even the majority in some places? How will racial understandings core to American society be altered as the Black immigrant population increases in many places as well?

And what about Trump? Some of the important patterns uncovered in this study of course pre-date the 2016 election, but it is likely that Trump has had an influence on the increased correlation between racial resentment and immigration policy attitudes, particularly for Democrats, and certainly this and other research has demonstrated the heightened importance of race and immigration in the 2016 election. Will these impacts confer lasting change in the relationship between race and immigration, as implied by the 2018 data, or will some of the findings above eventually be considered artifacts of the Trump era? Regardless, the combined findings of increased political polarization on race and immigration issues and the increasing correlation between racial resentment and 
immigration policy attitudes paint a picture of a nation increasingly divided along these

lines and perhaps, one that increasingly recognizes the link between the two issues. At the

very least, partisan issue sorting has likely made it such that fewer Americans now

combine conservative racial attitudes with liberal immigration attitudes or liberal racial

attitudes with conservative immigration attitudes than was true in the past. If polarizing

trends continue beyond 2020, this may be increasingly true in the future.

\section{References}

Ahmadi, Shafiqa. 2011. "The Erosion of Civil Rights: Exploring the Effects of the Patriot Act on Muslims in American Higher Education." Rutgers Race \& the Law Review 12: 1 .

Alba, Richard. 2018. "What Majority-Minority Society? A Critical Analysis of the Census Bureau's Projections of America's Demographic Future." Socius 4: 1-10.

Allport, Gordon Willard. 1954. The Nature of Prejudice. Boston: Addison-Wesley Publishing Company.

Baldassarri, Delia, and Barum Park. 2020. "Was There a Culture War? Polarization and Secular Trends in US Public Opinion.” Journal of Politics 82, no. 3 (July 2020): 809-827.

Bobo, Lawrence D., Camille Z. Charles, Maria Krysan, and Alicia D. Simmons. 2012. "The Real Record on Racial Attitudes." In Social Trends in American Life: Findings from the General Social Survey Since 1972, edited by Peter V. Marsden, 38-83. Princeton: Princeton University Press.

Chin, Gabriel J. 1996. "The Civil Rights Revolution Comes to Immigration Law: A New Look at the Immigration and Nationality Act of 1965." North Carolina Law Review 75: 273.

Craig, Maureen A., Julian M. Rucker, and Jennifer A. Richeson. 2018. "Racial and Political Dynamics of an Approaching 'Majority-Minority' United States." The ANNALS of the American Academy of Political and Social Science 677 (1): 204214.

DeSante, Christopher D, and Candis W Smith. 2018. "Fear, Institutionalized Racism, and Empathy (FIRE): A Holistic Measure of White Americans' 21st Century Racial Attitudes." In . Boston.

DeSante, Christopher D., and Candis Watts Smith. 2017. "Fear, Institutionalized Racism, and Empathy: The Underlying Dimensions of Whites' Racial Attitudes." PS:

Political Science \& Politics, 1-7.

Enos, Ryan D. 2017. The Space Between Us: Social Geography and Politics. Cambridge: Cambridge University Press.

Green, Jon, and Sean McElwee. 2019. "The Differential Effects of Economic Conditions and Racial Attitudes in the Election of Donald Trump." Perspectives on Politics 17 (2): 358-379. 
Ha, Shang E. 2010. "The Consequences of Multiracial Contexts on Public Attitudes Toward Immigration." Political Research Quarterly 63 (1): 29-42.

Hainmueller, Jens, and Michael J. Hiscox. 2010. "Attitudes Toward Highly Skilled and Low-Skilled Immigration: Evidence from a Survey Experiment." American Political Science Review 104 (01): 61-84.

Hainmueller, Jens, Michael J. Hiscox, and Yotam Margalit. 2015. "Do Concerns About Labor Market Competition Shape Attitudes Toward Immigration? New Evidence." Journal of International Economics 97 (1): 193-207.

Hainmueller, Jens, and Daniel J. Hopkins. 2014. "Public Attitudes Toward Immigration." Annual Review of Political Science 17: 225-49.

Hamilton, Tod G. 2019. Immigration and the Remaking of Black America. New York: Russell Sage Foundation.

Henderson, Timothy J. 2011. Beyond Borders: A History of Mexican Migration to the United States. Hoboken: John Wiley \& Sons.

Higham, John. 1955. Strangers in the Land.

Hopkins, Daniel J. 2010. "Politicized Places: Explaining Where and When Immigrants Provoke Local Opposition.” American Political Science Review 104 (01): 40-60.

Huber, Chuck, and David Drukker. 2015. "Introduction to Treatment Effects in Stata: Part 1." The Stata Blog (blog). July 7, 2015. https://blog.stata.com/2015/07/07/introduction-to-treatment-effects-in-stata-part$1 /$.

Jones, Bradley. 2019. "Majority of Americans Continue to Say Immigrants Strengthen the U.S." January 31, 2019. https://www.pewresearch.org/facttank/2019/01/31/majority-of-americans-continue-to-say-immigrants-strengthenthe-u-s/.

Kinder, Donald R., and Lynn M. Sanders. 1996. Divided by Color: Racial Politics and Democratic Ideals. Chicago: University of Chicago Press.

Kinder, Donald R., and David O. Sears. 1981. "Prejudice and Politics: Symbolic Racism Versus Racial Threats to the Good Life." Journal of Personality and Social Psychology 40 (3): 414.

Krogstad, Jens Manuel, and Jynnah Radford. 2018. "Education Levels of U.S. Immigrants Are on the Rise.” Pew Research Center. September 14, 2018. https://www.pewresearch.org/fact-tank/2018/09/14/education-levels-of-u-simmigrants-are-on-the-rise/.

Lee, Erika. 2002. "The Chinese Exclusion Example: Race, Immigration, and American Gatekeeping, 1882-1924." Journal of American Ethnic History 21 (3): 36-62.

Lieberson, Stanley. 1982. A Piece of the Pie. Berkeley: University of California Press.

Lopez, Ian Haney. 1997. White by Law: The Legal Construction of Race. New York: NYU Press.

Marrow, Helen. 2011. New Destination Dreaming: Immigration, Race, and Legal Status in the Rural American South. Stanford: Stanford University Press.

Martin, Susan, B. Lindsay Lowell, and Philip Martin. 2001. "US Immigration Policy: Admission of High Skilled Workers." Geo. Immigr. LJ 16: 619.

Massey, Douglas S. 2008. New Faces in New Places: The Changing Geography of American Immigration. New York: Russell Sage Foundation. 
Massey, Douglas S., and Karen A. Pren. 2012. "Unintended Consequences of U.S. Immigration Policy: Explaining the Post-1965 Surge from Latin America." Population and Development Review 38 (1): 1-29.

Mayda, Anna Maria, Giovanni Peri, and Walter Steingress. 2018. "The Political Impact of Immigration: Evidence from the United States.” Working Paper 24510. Working Paper Series. National Bureau of Economic Research. https://doi.org/10.3386/w24510.

Migration Policy Institute. 2019. "Mexican-Born Population Over Time, 1850-Present." Migration Policy Institute. 2019. https://www.migrationpolicy.org/programs/datahub/charts/mexican-born-population-over-time.

Miller, Steven V. 2018. "Economic Anxiety or Racial Resentment? An Evaluation of Attitudes Toward Immigration in the U.S. From 1992 to 2016.” Working Paper. Immigration Research. 2018. https://www.immigrationresearch.org/system/files/Attitudes_Toward_Immigratio n_1992-2016.pdf.

Morning Consult. 2017. "National Tracking Poll \#170916: Crosstabulation Results." September 22, 2017. https://morningconsult.com/wpcontent/uploads/2017/10/170916_crosstabs_pr_v1_KD.pdf.

Mutz, Diana C. 2018. "Status Threat, Not Economic Hardship, Explains the 2016 Presidential Vote." Proceedings of the National Academy of Sciences 115 (19): E4330-39.

Myers, Dowell, and Morris Levy. 2018. "Racial Population Projections and Reactions to Alternative News Accounts of Growing Diversity." The ANNALS of the American Academy of Political and Social Science 677 (1): 215-228.

Neville, Helen A., Roderick L. Lilly, Georgia Duran, Richard M. Lee, and LaVonne Browne. 2000. "Construction and Initial Validation of the Color-Blind Racial Attitudes Scale (Cobras).” Journal of Counseling Psychology 47 (1): 59.

Newman, Benjamin J. 2013. "Acculturating Contexts and Anglo Opposition to Immigration in the United States." American Journal of Political Science 57 (2): 374-390.

Newman, Benjamin J., and Neil Malhotra. 2019. "Economic Reasoning with a Racial Hue: Is the Immigration Consensus Purely Race Neutral?" The Journal of Politics 81 (1): 153-166.

Newman, Benjamin J., Sono Shah, and Loren Collingwood. 2018. "Race, Place, and Building a Base: Latino Population Growth and the Nascent Trump Campaign for President." Public Opinion Quarterly 82 (1): 122-34.

Ngai, Mae M. 1999. "The Architecture of Race in American Immigration Law: A Reexamination of the Immigration Act of 1924." The Journal of American History 86 (1): 67-92.

Pettigrew, Thomas F., and Linda R. Tropp. 2006. "A Meta-Analytic Test of Intergroup Contact Theory." Journal of Personality and Social Psychology 90 (5): 751-83.

Pew Research Center. 2015. "Modern Immigration Wave Brings 59 Million to U.S., Driving Population Growth and Change Through 2065: Views of Immigration's Impact on U.S. Society Mixed." Washington, D.C.: Pew Research Center. http://www.pewhispanic.org/2015/09/28/modern-immigration-wave-brings-59million-to-u-s-driving-population-growth-and-change-through-2065/. 
- 2017. "The Partisan Divide on Political Values Grows Even Wider.” Pew Research Center: U.S. Politics \& Policy. October 5, 2017. https://www.peoplepress.org/2017/10/05/4-race-immigration-and-discrimination/.

Pierce, Sarah. 2019. "Immigration-Related Policy Changes in the First Two Years of the Trump Administration.” Migration Policy Institute. May 2019. https://www.migrationpolicy.org/research/immigration-policy-changes-two-yearstrump-administration.

Quillian, Lincoln. 1996. "Group Threat and Regional Change in Attitudes Toward African-Americans.” American Journal of Sociology 102 (3): 816-60.

Reny, Tyler T., Loren Collingwood, and Ali A. Valenzuela. 2019. "Vote Switching in the 2016 Election: How Racial and Immigration Attitudes, Not Economics, Explain Shifts in White Voting." Public Opinion Quarterly 83 (1): 91-113.

Rieder, Jonathan. 1985. Canarsie: The Jews and Italians of Brooklyn Against Liberalism. Cambridge: Harvard University Press.

Roediger, David R. 2005. Working Toward Whiteness: How America's Immigrants Became White: The Strange Journey from Ellis Island to the Suburbs. New York, NY: Basic Books.

Sides, John. 2017. "Race, Religion, and Immigration in 2016: How the Debate over American Identity Shaped the Election and What It Means for a Trump Presidency." Washington, D.C.: Democracy Fund Voter Study Group.

Silver, Nate. 2016. "The Odds Of An Electoral College-Popular Vote Split Are Increasing." FiveThirtyEight. October 31, 2016. https:/fivethirtyeight.com/features/the-odds-of-an-electoral-college-popular-votesplit-are-increasing/.

StataCorp. 2013. "Stata Treatment-Effects Reference Manual: Potential Outcomes/Counterfactual Outcomes.” 2013. https://www.stata.com/manuals13/te.pdf.

Street, Alex, Chris Zepeda-Millán, and Michael Jones-Correa. 2015. "Mass Deportations and the Future of Latino Partisanship." Social Science Quarterly 96 (2): 540-552.

Waters, Mary C. 1994. "Ethnic and Racial Identities of Second-Generation Black Immigrants in New York City." International Migration Review 28 (4): 795-820.

Wheelock, Darren, and Douglas Hartmann. 2007. "Midnight Basketball and the 1994 Crime Bill Debates: The Operation of a Racial Code." The Sociological Quarterly 48 (2): 315-342. 
Figure 1: Percentage saying immigration should be reduced or increased by year and sub-population, 1994-2018

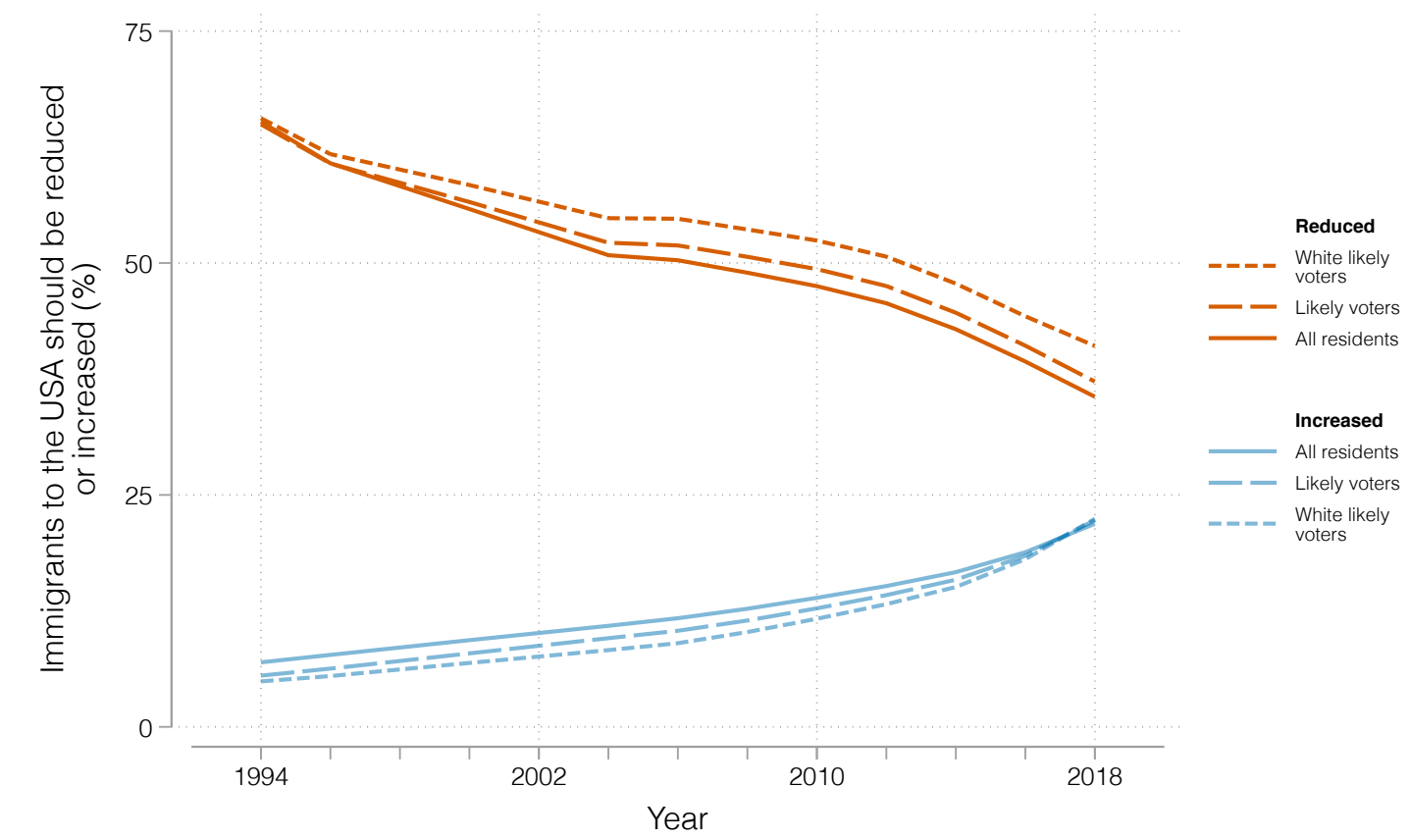

Note: We smoothed the raw data to reduce the influence of annual sampling variations on interpretations

Source: Authors' calculations from the General Social Surveys, 1994-2018. 
Figure 2: Preference for reducing immigration by year and political party: non-Hispanic White likely voters, 1994-2018

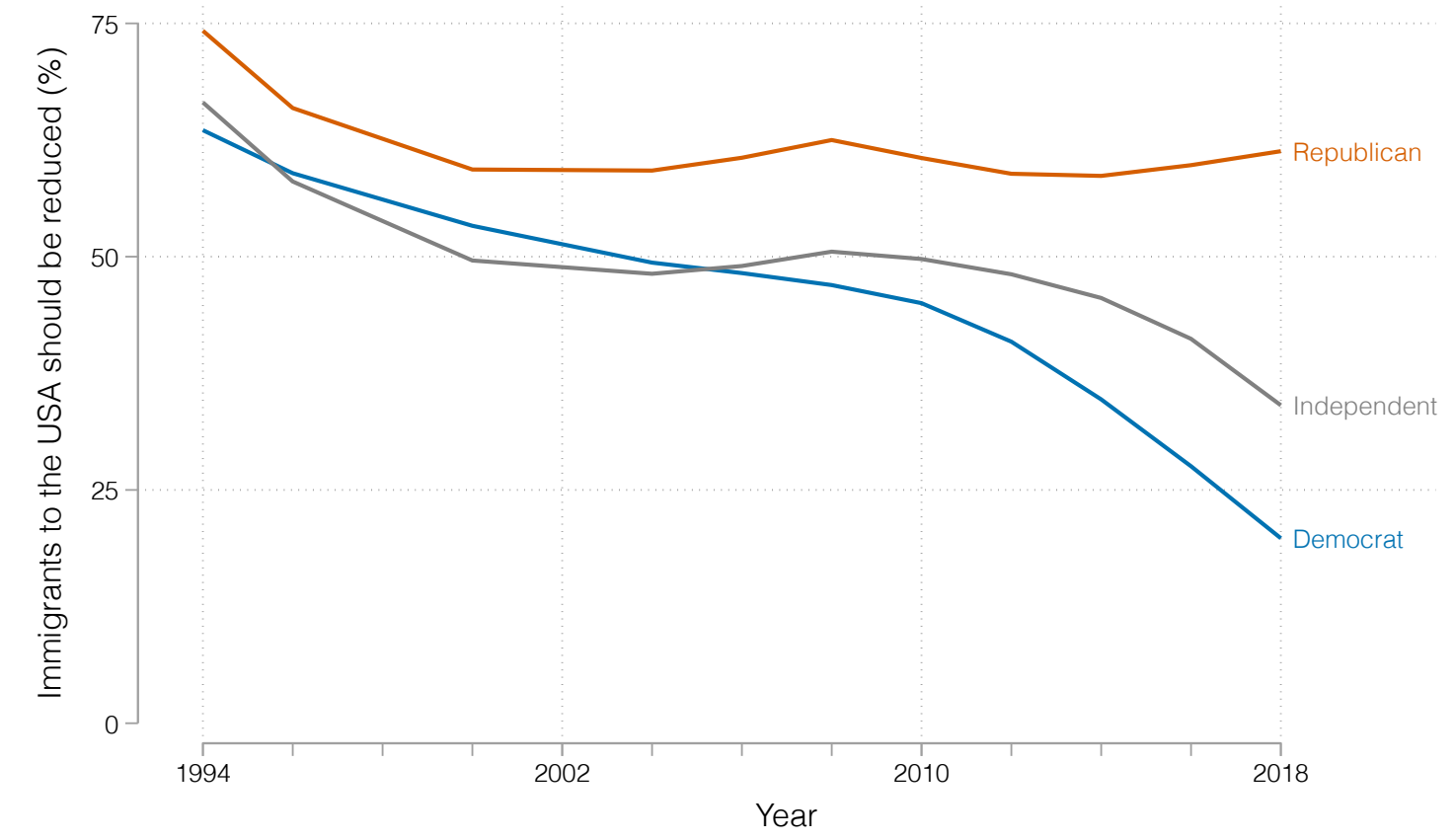

Note: We smoothed the raw data to reduce the influence of annual sampling variations on interpretations.

Source: Authors' calculations from the General Social Surveys, 1994-2018. 
Figure 3: Racial resentment by year and political party: non-Hispanic White likely voters, 1994-2018

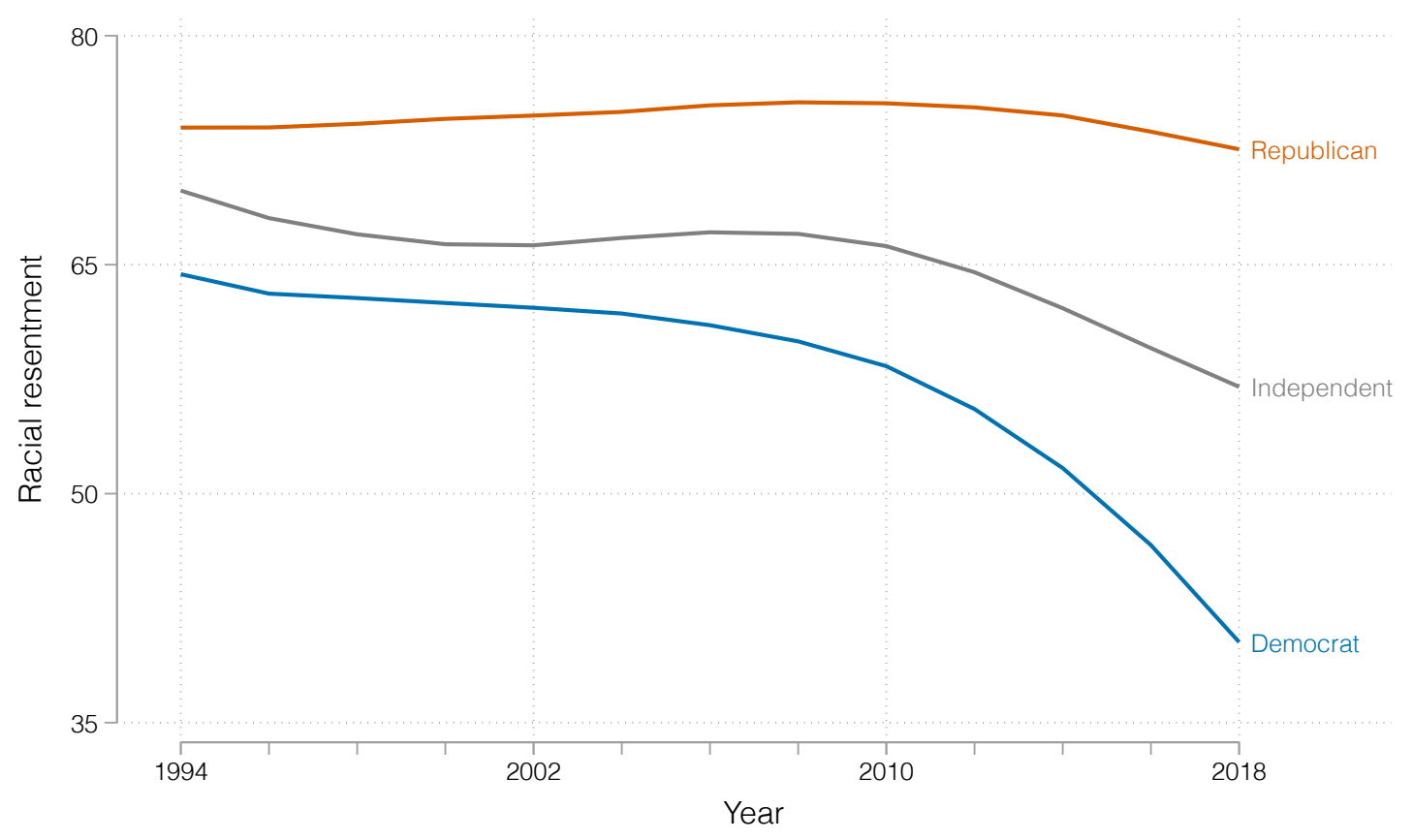

Note: We smoothed the raw data to reduce the influence of annual sampling variations on interpretations.

Source: Authors' calculations from the General Social Surveys, 1994-2018. 


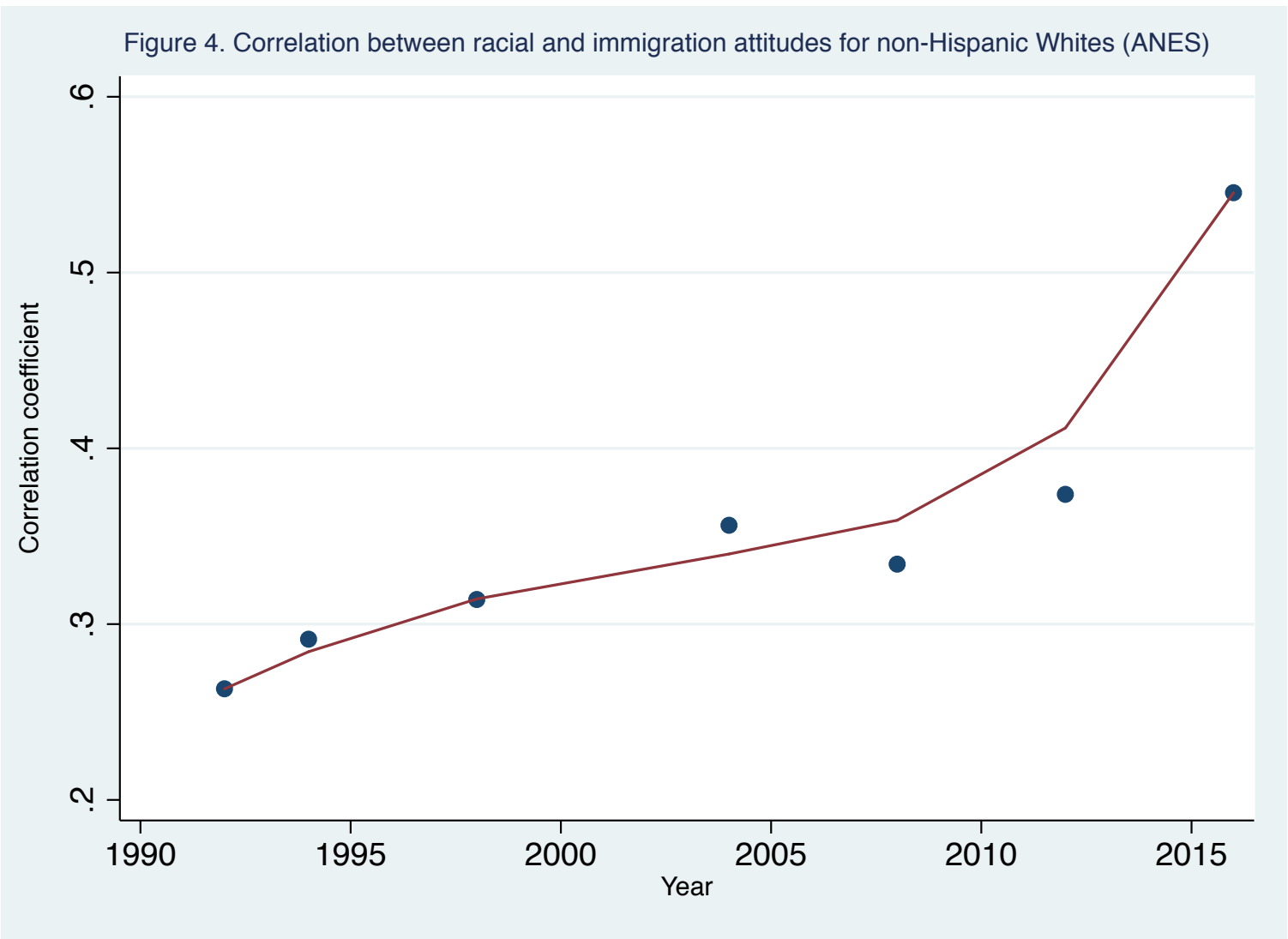

Note: We smoothed the raw data to reduce the influence of annual sampling variations on interpretations

Source: Authors' calculations from the American National Election Studies, 1992-2016. 


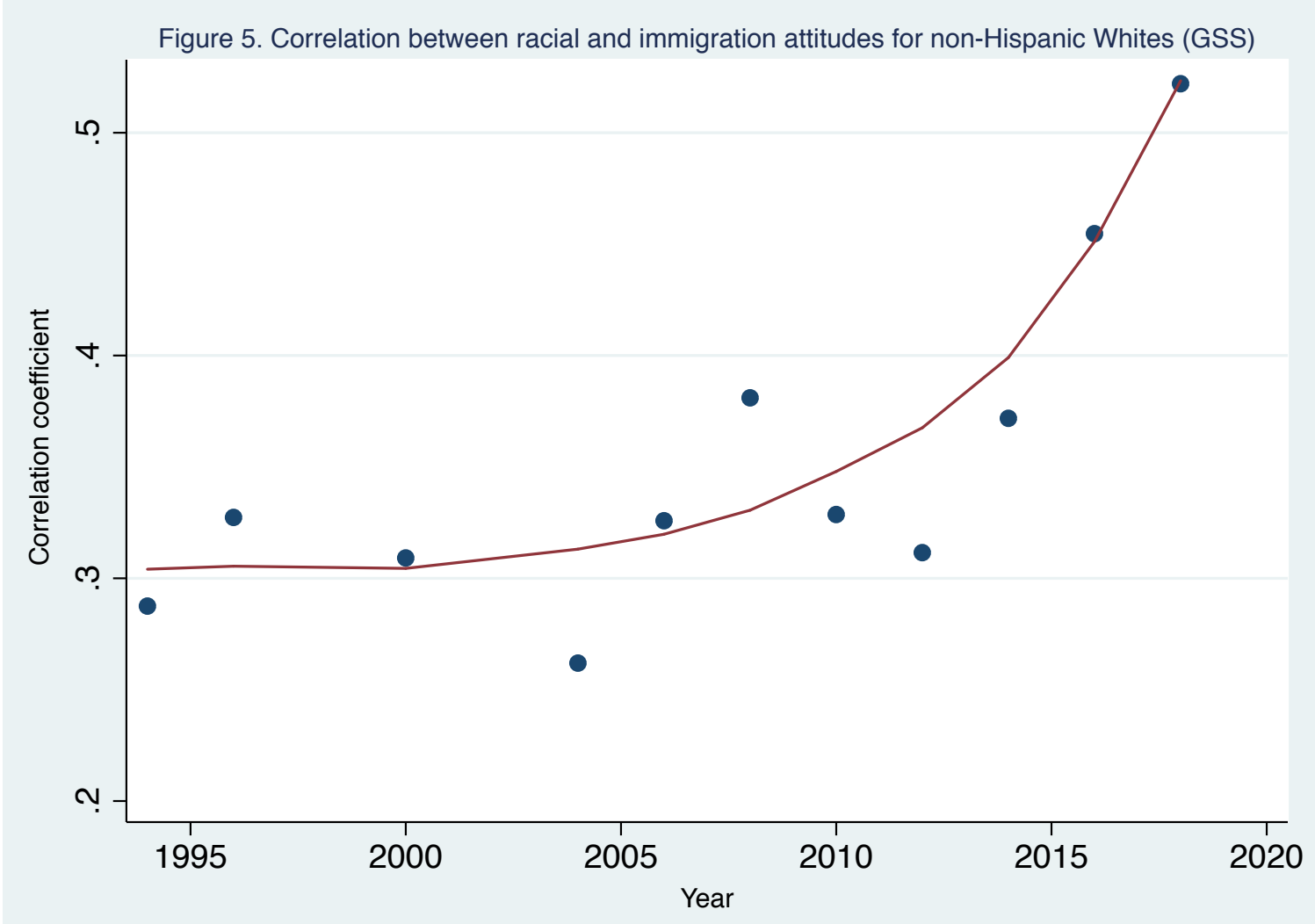

Note: We smoothed the raw data to reduce the influence of annual sampling variations on interpretations.

Source: Authors' calculations from the General Social Surveys, 1994-2018. 
Figure 6. Correlation between racial and immigration attitudes for non-Hispanic Whites by party ID (ANES)

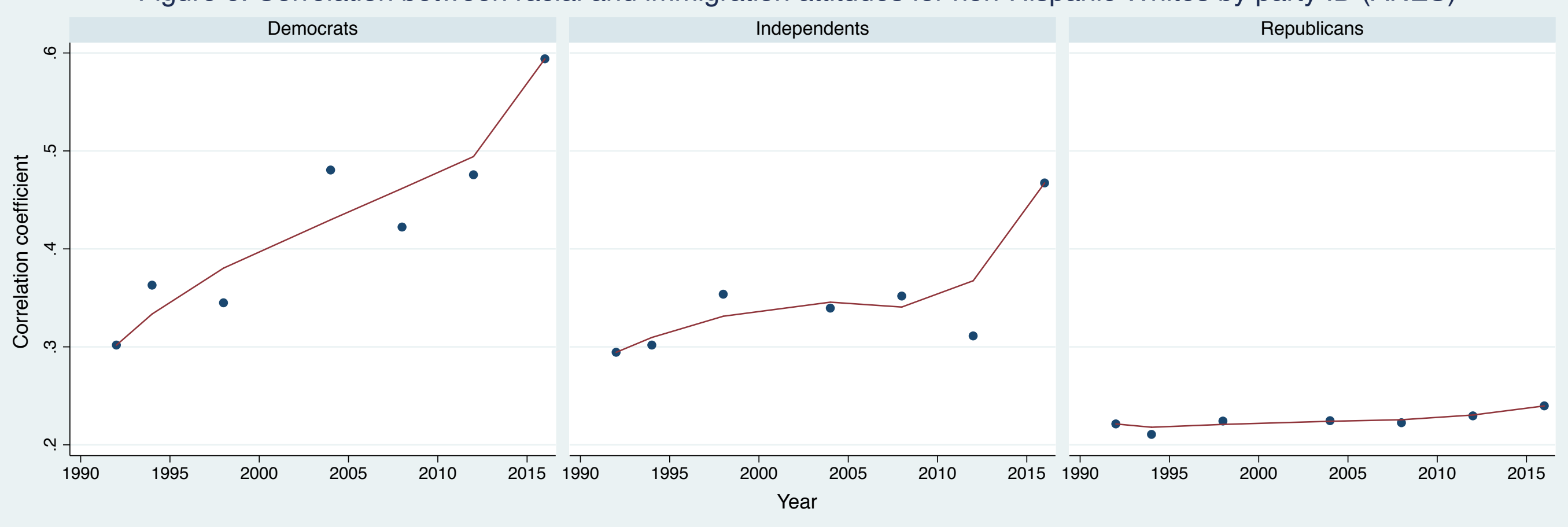

Note: We smoothed the raw data to reduce the influence of annual sampling variations on interpretations.

Source: Authors' calculations from the American National Election Studies, 1992-2016. 




Note: We smoothed the raw data to reduce the influence of annual sampling variations on interpretations.

Source: Authors' calculations from the General Social Surveys, 1994-2018. 
Table 1: OLS regressions predicting conservative immigration policy attitude scale with conservative racial attitude scale: non-Hispanic Whites

\begin{tabular}{|c|c|c|c|c|c|c|}
\hline Variables & Baseline & Plus demographics & Plus socioeconomics & Plus contextual & Plus economic assessments & Plus political ideology \\
\hline Conservative racial attitude scale & $\begin{array}{l}0.27^{* * * *} \\
(0.0019)\end{array}$ & $\begin{array}{l}0.27 * * * \\
(0.0019)\end{array}$ & $\begin{array}{l}0.26^{* * * *} \\
(0.0020)\end{array}$ & $\begin{array}{l}0.25 * * * \\
(0.0020)\end{array}$ & $\begin{array}{l}0.19^{* * *} \\
(0.0021)\end{array}$ & $\begin{array}{l}0.15^{* * * *} \\
(0.0022)\end{array}$ \\
\hline Female & & $\begin{array}{c}0.0023 \\
(0.0031)\end{array}$ & $\begin{array}{c}-0.010^{* * *} \\
(0.0033)\end{array}$ & $\begin{array}{c}-0.012 * * * \\
(0.0033)\end{array}$ & $\begin{array}{c}-0.029 * * * \\
(0.0032)\end{array}$ & $\begin{array}{c}-0.022 * * * \\
(0.0031)\end{array}$ \\
\hline Birth year & & $\begin{array}{c}-0.0022^{* * *} \\
(0.00013)\end{array}$ & $\begin{array}{c}-0.0022^{* * *} \\
(0.00015)\end{array}$ & $\begin{array}{c}-0.0021^{* * *} \\
(0.00016)\end{array}$ & $\begin{array}{c}-0.0016^{* * *} \\
(0.00016)\end{array}$ & $\begin{array}{c}-0.0011^{* * *} \\
(0.00015)\end{array}$ \\
\hline Child under 18 years & & $\begin{array}{l}0.0074^{*} \\
(0.0043)\end{array}$ & $\begin{array}{l}0.0074^{*} \\
(0.0043)\end{array}$ & $\begin{array}{c}0.0060 \\
(0.0043)\end{array}$ & $\begin{array}{c}0.0034 \\
(0.0041)\end{array}$ & $\begin{array}{c}-0.0033 \\
(0.0040)\end{array}$ \\
\hline \multicolumn{7}{|l|}{ Marital status (ref. $=$ married) } \\
\hline Separated & & $\begin{array}{l}0.0029 \\
(0.014)\end{array}$ & $\begin{array}{l}-0.015 \\
(0.014)\end{array}$ & $\begin{array}{l}-0.012 \\
(0.014)\end{array}$ & $\begin{array}{l}-0.0086 \\
(0.013)\end{array}$ & $\begin{array}{l}-0.0053 \\
(0.013)\end{array}$ \\
\hline Divorced & & $\begin{array}{c}0.0028 \\
(0.0050)\end{array}$ & $\begin{array}{l}-0.011 * * \\
(0.0052)\end{array}$ & $\begin{array}{l}-0.0065 \\
(0.0052)\end{array}$ & $\begin{array}{l}-0.0044 \\
(0.0050)\end{array}$ & $\begin{array}{c}0.0041 \\
(0.0048)\end{array}$ \\
\hline Widowed & & $\begin{array}{l}0.00067 \\
(0.0070)\end{array}$ & $\begin{array}{l}-0.0075 \\
(0.0071)\end{array}$ & $\begin{array}{l}-0.0039 \\
(0.0071)\end{array}$ & $\begin{array}{c}-0.0064 \\
(0.0067)\end{array}$ & $\begin{array}{l}-0.0049 \\
(0.0065)\end{array}$ \\
\hline Single & & $\begin{array}{c}-0.020 * * * \\
(0.0047)\end{array}$ & $\begin{array}{c}-0.028 * * * \\
(0.0050)\end{array}$ & $\begin{array}{c}-0.024 * * * \\
(0.0050)\end{array}$ & $\begin{array}{c}-0.018^{* * *} \\
(0.0048)\end{array}$ & $\begin{array}{c}-0.0094^{* *} \\
(0.0046)\end{array}$ \\
\hline Domestic partnership & & $\begin{array}{c}-0.019^{* *} \\
(0.0078)\end{array}$ & $\begin{array}{c}-0.029 * * * \\
(0.0078)\end{array}$ & $\begin{array}{c}-0.025 * * * \\
(0.0078)\end{array}$ & $\begin{array}{l}-0.018^{* *} \\
(0.0074)\end{array}$ & $\begin{array}{c}0.0035 \\
(0.0072)\end{array}$ \\
\hline \multicolumn{7}{|l|}{ Citizenship/nativity (ref. $=$ foreign-born citizen) } \\
\hline Foreign-born non-citizen & & $\begin{array}{l}-0.019 \\
(0.022)\end{array}$ & $\begin{array}{l}-0.025 \\
(0.021)\end{array}$ & $\begin{array}{l}-0.020 \\
(0.021)\end{array}$ & $\begin{array}{l}-0.0098 \\
(0.020)\end{array}$ & $\begin{array}{l}-0.0089 \\
(0.020)\end{array}$ \\
\hline Second generation (at least 1 foreign-born parent) & & $\begin{array}{l}0.0042 \\
(0.011)\end{array}$ & $\begin{array}{l}0.0048 \\
(0.011)\end{array}$ & $\begin{array}{l}0.0045 \\
(0.011)\end{array}$ & $\begin{array}{l}-0.0100 \\
(0.011)\end{array}$ & $\begin{array}{l}-0.013 \\
(0.010)\end{array}$ \\
\hline Third generation (at least 1 foreign-born grandparent) & & $\begin{array}{l}0.022 * * \\
(0.0098)\end{array}$ & $\begin{array}{l}0.020 * * \\
(0.0097)\end{array}$ & $\begin{array}{c}0.017^{*} \\
(0.0098)\end{array}$ & $\begin{array}{c}0.0025 \\
(0.0093)\end{array}$ & $\begin{array}{l}-0.0018 \\
(0.0090)\end{array}$ \\
\hline Fourth generation + & & $\begin{array}{c}0.042 * * * \\
(0.0095)\end{array}$ & $\begin{array}{c}0.032^{* * *} \\
(0.0094)\end{array}$ & $\begin{array}{c}0.025^{* * *} \\
(0.0094)\end{array}$ & $\begin{array}{c}0.011 \\
(0.0090)\end{array}$ & $\begin{array}{c}0.0035 \\
(0.0087)\end{array}$ \\
\hline \multicolumn{7}{|l|}{ Education (ref. = less than high school) } \\
\hline High school graduate & & & $\begin{array}{c}0.010 \\
(0.011)\end{array}$ & $\begin{array}{l}0.0100 \\
(0.011)\end{array}$ & $\begin{array}{l}0.0068 \\
(0.011)\end{array}$ & $\begin{array}{l}0.0096 \\
(0.010)\end{array}$ \\
\hline Some college & & & $\begin{array}{l}-0.0090 \\
(0.011)\end{array}$ & $\begin{array}{l}-0.0065 \\
(0.011)\end{array}$ & $\begin{array}{l}-0.0016 \\
(0.011)\end{array}$ & $\begin{array}{l}0.0014 \\
(0.010)\end{array}$ \\
\hline 2-year degree & & & $\begin{array}{l}-0.0063 \\
(0.012)\end{array}$ & $\begin{array}{l}-0.0042 \\
(0.012)\end{array}$ & $\begin{array}{c}-0.00057 \\
(0.011)\end{array}$ & $\begin{array}{l}0.0030 \\
(0.011)\end{array}$ \\
\hline 4-year degree & & & $\begin{array}{c}-0.052 * * * \\
(0.011)\end{array}$ & $\begin{array}{c}-0.047 * * * \\
(0.011)\end{array}$ & $\begin{array}{c}-0.029 * * * \\
(0.011)\end{array}$ & $\begin{array}{c}-0.023^{* *} \\
(0.010)\end{array}$ \\
\hline
\end{tabular}




$\begin{array}{cc}-0.083^{* * *} & -0.078^{* * *} \\ (0.012) & (0.012) \\ & \\ -0.018^{*} & -0.019^{*} \\ (0.011) & (0.011) \\ -0.012 & -0.012 \\ (0.010) & (0.010) \\ -0.021^{* *} & -0.021^{* *} \\ (0.010) & (0.010) \\ -0.017^{*} & -0.016 \\ (0.010) & (0.010) \\ -0.017^{*} & -0.015 \\ (0.011) & (0.011) \\ -0.020^{*} & -0.016 \\ (0.011) & (0.011) \\ -0.022^{* *} & -0.018^{*} \\ (0.011) & (0.011) \\ -0.030^{* * *} & -0.026^{* *} \\ (0.011) & (0.011) \\ -0.040^{* * *} & -0.035^{* * *} \\ (0.011) & (0.011) \\ -0.034^{* * *} & -0.029^{* *} \\ (0.011) & (0.012) \\ -0.036^{* * *} & -0.028^{* *} \\ (0.012) & (0.012) \\ 0.014 & 0.017^{*} \\ (0.010) & (0.010) \\ & \\ -0.010^{*} & -0.0096^{*} \\ (0.0055) & (0.0055) \\ -0.0090 & -0.0082 \\ (0.022) & (0.022) \\ 0.0067 & 0.0056 \\ (0.0081) & (0.0081) \\ -0.038^{* * *} & -0.037^{* * *} \\ (0.0051) & (0.0051) \\ 0.017 * * & 0.013 * \\ (0.0069) & (0.0069) \\ -0.0060 & -0.0075 \\ (0.0064) & (0.0064) \\ & \end{array}$

$-0.053^{* * *}$
$(0.011)$

-0.014
$(0.010)$
-0.0070
$(0.0097)$
-0.011
$(0.0097)$
-0.0025
$(0.0099)$
-0.00030
$(0.010)$
0.0066
$(0.010)$
0.0046
$(0.010)$
0.0037
$(0.010)$
-0.0014
$(0.011)$
0.0087
$(0.011)$
0.0088
$(0.011)$
$0.023^{* *}$
$(0.0098)$

$-0.014^{* * *}$
$(0.0052)$
-0.025
$(0.021)$
$-0.016 * *$
$(0.0078)$
$-0.033^{* * *}$
$(0.0048)$
0.0010
$(0.0066)$
$-0.011 *$
$(0.0061)$

Family income (ref. $=$ less than $\$ 10,000)$

$\$ 10,000$ - $\$ 19,999$

$\$ 20,000$ - $\$ 29,999$

$\$ 30,000$ - $\$ 39,999$

$\$ 40,000$ - $\$ 49,999$

$\$ 50,000-\$ 59,999$

$\$ 60,000$ - $\$ 69,999$

$\$ 70,000$ - $\$ 79,999$

$\$ 80,000$ - $\$ 99,999$

$\$ 100,000$ - \$119,999

$\$ 120,000-\$ 149,999$

$\$ 150,000$ or greater

Prefer not to say

Employment status (ref. $=$ full-time)

$$
\text { Part-time }
$$

Temporarily laid off

Unemployed

Retired

Permanently disabled

Homemaker 
Union membership (ref. $=$ never)

\section{Current}

Former

$-0.021 * * *$

$(0.0062)$

$-0.0032$

Pct. non-Hispanic White '10-14 (county-level)

0.000048

0.000048
$(0.00014)$

$-0.0099 * * *$

$(0.011)$

Logged population density '10-14 (county-level)

Time at current residence (ref. = less than 1 year)

5 or more years

Current city residence length in years

State of residence $($ ref. $=$ Alabama $)$

$$
\text { Alaska }
$$

\section{Arizona}

Arkansas

California

Colorado

Connecticut

\section{Delaware}

District of Columbia

$(0.0069)$

$0.026^{* * *}$

(0.0061)

$-0.00040^{* * *}$

(0.0066)

0.0093

(0.0066)

$0.020 * * *$

$(0.0058)$

$-0.00038^{* * *}$

(0.0013)

$-0.083 * *$

$(0.038)$

$-0.043^{* *}$

$(0.017)$

$(0.022)$

$-0.044 * * *$

$(0.016)$

$-0.043^{* *}$
$(0.019)$

$(0.019)$

$(0.020)$

$-0.052^{*}$

$(0.028)$

$-0.089^{* * *}$

$(0.038)$

(0.00011)

0.0031

(0.0064)

$0.012 *$

$(0.0064)$
$0.020 * * *$

(0.0056)

$-0.00039 * * *$

(0.00010)

$-0.093 * * *$

$-0.078^{* *}$

$(0.036)$

$-0.025$

$(0.017)$
-0.023

$-0.023$

$-0.022$

$(0.015)$

$-0.019$

(0.018)

$-0.032$

$(0.019)$

$-0.032$

$(0.027)$
$-0.060^{*}$

$(0.036)$ 


Georgia
Hawaii
Idaho
Illinois
Indiana
Iowa
Kansas
Kentucky
Louisiana
Maine
Maryland
Massachusetts
Michigan
Minnesota
Mississippi
Missouri
Montana
Nebraska
Nevada

$\begin{array}{ccc}(0.016) & (0.015) & (0.014) \\ -0.013 & -0.0010 & -0.010 \\ (0.017) & (0.016) & (0.016) \\ -0.061 & -0.047 & -0.036 \\ (0.039) & (0.037) & (0.036) \\ -0.065^{* * *} & -0.033 & -0.039^{*} \\ (0.024) & (0.023) & (0.022) \\ -0.047^{* * *} & -0.029^{*} & -0.024 \\ (0.016) & (0.016) & (0.015) \\ -0.031^{*} & -0.011 & -0.016 \\ (0.017) & (0.017) & (0.016) \\ -0.066^{* * *} & -0.037^{* *} & -0.029 \\ (0.019) & (0.018) & (0.018) \\ -0.067^{* * *} & -0.041^{* *} & -0.041 * * \\ (0.021) & (0.020) & (0.020) \\ -0.032^{*} & -0.014 & -0.015 \\ (0.019) & (0.018) & (0.017) \\ -0.0092 & -0.017 & -0.023 \\ (0.021) & (0.020) & (0.019) \\ -0.054^{* *} & -0.029 & -0.022 \\ (0.023) & (0.022) & (0.021) \\ -0.022 & -0.0096 & -0.0073 \\ (0.019) & (0.018) & (0.017) \\ -0.022 & -0.0070 & 0.0014 \\ (0.018) & (0.017) & (0.016) \\ -0.045^{* * *} & -0.015 & -0.013 \\ (0.017) & (0.016) & (0.015) \\ -0.066^{* * *} & -0.037 * * & -0.033^{* *} \\ (0.018) & (0.017) & (0.017) \\ -0.037 & -0.029 & -0.031 \\ (0.026) & (0.025) & (0.024) \\ -0.036^{* *} & -0.017 & -0.018 \\ (0.018) & (0.017) & (0.016) \\ -0.060^{* *} & -0.043 & -0.048^{*} \\ (0.028) & (0.026) & (0.026) \\ -0.028 & -0.018 & -0.021 \\ (0.023) & (0.022) & -0.021) \\ -0.071^{* * *} & -0.037^{*} & (0.019) \\ (0.021) & (0.020) & -0.0057 \\ -0.031 & -0.0093 & \\ & & \end{array}$




\section{Wyoming}

National economy in the past year (ref. = gotten much better) Gotten better

\section{Stayed about the same}

Gotten worse

Gotten much worse

Not sure

Household income in the past four years (ref. $=$ increased a lot) Increased somewhat

Stayed about the same

Decreased somewhat

\section{Decreased a lot}

National economy in the next year will (ref. = get much better) Get somewhat better

\section{Stay about the same}

Get somewhat worse

\section{Get much worse}

Not sure

Political ideology $($ ref. $=$ very liberal $)$ Liberal

Moderate

Conservative
$(0.017)$
$-0.12 * * *$

(0.037)

(0.017)

$-0.096^{* * * *}$

(0.036)

0.0043

(0.0088)

$0.13 * * *$

(0.0091)

$0.23^{* * *}$

$(0.0095)$

$0.28^{* * *}$
$(0.010)$

$0.10^{* * * *}$

(0.013)

$-0.0015$

(0.0069)

$0.020^{* * *}$

(0.0072)

$0.023 * * *$

(0.0078)

$0.024^{* * *}$

$(0.0087)$

$-0.033^{* * *}$

(0.0096)

$-0.011$

(0.0098)

0.0044

$(0.010)$

0.0081

$(0.011)$

0.0083

(0.010)
(0.016)

$-0.093 * * *$
$(0.034)$

$-0.000091$

$(0.0085)$

$0.093^{* * *}$

$(0.0089)$

$0.17^{* * *}$

(0.0093)

$0.21^{* * *}$

$(0.010)$

$0.065^{* * *}$

(0.013)

0.0011

$(0.0067)$

$0.022^{* * *}$

$(0.0070)$

$0.024 * * *$

$(0.0076)$

$0.028^{* * *}$

(0.0084)

$-0.026^{* * *}$

(0.0093)

$-0.011$

$(0.0095)$

$-0.0024$

(0.0099)

0.0061

$(0.011)$

0.0026

(0.0097)

$0.048^{* * * *}$

(0.0057)

$0.15^{* * *}$

$(0.0056)$

$0.24 * * *$ 
$-0.11 * * *$

(0.0046)

$4.11^{* * *}$

$(0.25)$

37,632

37,632

37,632
0.356

0.345

R-squared

Standard errors in parentheses

$* * * \mathrm{p}<0.01,{ }^{* *} \mathrm{p}<0.05, * \mathrm{p}<0.1$

Sources: Authors' calculations from the Cooperative Congressional Election Study, 2016 and the American Community Survey, 2010-2014
$0.29 * * *$

(0.0074)

$0.18 * * *$

(0.0080)

$2.07 * * *$

(0.30)

37,632 
Table 2: OLS regressions predicting conservative immigration policy attitude scale with FIRE items: non-Hispanic Whites

Variables

Whites have advantages

Racial problems are rare/isolated

Fearful of other races

Angry racism exists

Female

Birth year

Child under 18 years

Marital status (ref. $=$ married)

Separated

Divorced

Widowed

Single

Domestic partnership

Citizenship/nativity (ref. $=$ foreign-born citizen)

Foreign-born non-citizen

Second generation (at least 1 foreign-born parent)

Third generation (at least 1 foreign-born grandparent)

Fourth generation+

Education (ref. $=$ less than high school)

High school graduate
Baseline Plus demographics

Plus socioeconomics

Plus contextua

$-0.11^{* * *}$

$(0.0012)$

$.038^{* * *}$

$0.0014)$

$(0.0014)$

$0.048^{* *}$

$(0.0018)$

$-0.11^{* * *}$
$(0.0012)$
$0.039^{* * *}$
$(0.0014)$
$0.041^{* * *}$
$(0.0014)$
$-0.047^{* * *}$
$(0.0018)$
$-0.0086^{* * *}$
$(0.0031)$
$-0.0019^{* * *}$
$(0.00012)$
0.0057
$(0.0042)$

(0.0042)

$-0.0050$

(0.013)

$-0.00012$

$(0.0049)$

0.000032

(0.0068)

$-0.015^{* * *}$

$(0.0047)$

$-0.021^{* *}$

(0.0077)

$-0.018$

$(0.021)$

$-0.016$

$(0.011)$

0.00072

$(0.0097)$

$0.018^{*}$
$(0.0093)$
$-0.11^{* * *}$

(0.0013)

$0.040 * * *$
$(0.0014)$

$0.040^{* * * *}$

(0.0014)

$-0.048 * * *$

(0.0018)

$-0.017 * * *$

$-0.0020 * *$

$(0.00015)$

0.0060

(0.0043)

$-0.019$

(0.014)

-0.011 **

$(0.0051)$
-0.0062

$(0.0070)$

$-0.022 * * *$
$(0.0049)$

$-0.029 * * *$

(0.0077)

$-0.023$

$(0.021)$

$-0.014$

(0.011)

0.00040

(0.0096)

0.013

(0.0093)

0.0096

$-0.10^{* * *}$
$(0.0013)$
$0.040^{* * *}$
$(0.0014)$
$0.040^{* * *}$
$(0.0014)$
$-0.048^{* * *}$
$(0.0018)$
$-0.018^{* * *}$
$(0.0033)$
$-0.0019^{* * *}$
$(0.00016)$
0.0048
$(0.0043)$

Plus economic

assessments

Plus political ideology

$-0.060^{* * *}$
$(0.0013)$
$0.021^{* * *}$
$(0.0014)$
$0.028^{* * *}$
$(0.0013)$
$-0.033^{* * *}$
$(0.0017)$
$-0.024^{* * *}$
$(0.0031)$
$-0.0010^{* * *}$
$(0.00015)$
-0.0031
$(0.0040)$

-0.0078
$(0.013)$
0.0029
$(0.0048)$
-0.0046
$(0.0065)$
$-0.0078^{*}$
$(0.0046)$
0.0015
$(0.0072)$

-0.0070
$(0.020)$
$-0.021^{* *}$
$(0.010)$
-0.0099
$(0.0090)$
-0.0041
$(0.0087)$
0.0094


Some college

$(0.011)$

$-0.0071$

$(0.011)$

2-year degree

$-0.0044$

$(0.011)$

4-year degree

Post-graduate degree

$(0.011)$

$-0.065^{* * *}$

$(0.012)$

$(0.011)$
-0.0051

$(0.011)$

$-0.0027$

$(0.011)$

$-0.033^{* * *}$

(0.011)

$-0.062 * * *$

-0.0010
$(0.011)$

$4.8 \mathrm{e}-06$

$(0.011)$

$-0.022^{* *}$

$(0.011)$

$-0.045^{* * *}$

$(0.011)$

$-0.022 * *$

$-0.021 * *$

$(0.010)$
-0.016

$(0.010)$

$\$ 20,000$ - $\$ 29,999$

$\$ 30,000-\$ 39,999$

$\$ 40,000$ - $\$ 49,999$

$\$ 50,000$ - $\$ 59,999$

$\$ 60,000$ - $\$ 69,999$

$\$ 70,000$ - \$79,999

$\$ 80,000$ - $\$ 99,999$

$\$ 100,000$ - \$119,999

$\$ 120,000$ - \$149,999

$\$ 150,000$ or greater

Prefer not to say

Employment status (ref. $=$ full-time) Part-time

Temporarily laid off

Unemployed 
Retired

Permanently disabled

Homemaker

Student

Other

Union membership (ref. $=$ never $)$

Current

Former

Pct. non-Hispanic White '10-14 (county-level)

Logged population density '10-14 (county-level)

Time at current residence (ref. $=$ less than 1 year) 1-2 years

3-4 years

5 or more years

Current city residence length in years

State of residence $($ ref. $=$ Alabama $)$ Alaska

Arizona

Arkansas

California

Colorado

\begin{tabular}{|c|c|c|c|}
\hline$(0.0080)$ & $(0.0080)$ & $(0.0077)$ & $(0.0075)$ \\
\hline$-0.029 * * *$ & $-0.027 * * *$ & $-0.027 * * *$ & $-0.027 * * *$ \\
\hline$(0.0050)$ & $(0.0050)$ & $(0.0048)$ & $(0.0047)$ \\
\hline $0.013 *$ & 0.010 & 0.00023 & 0.0077 \\
\hline$(0.0068)$ & $(0.0068)$ & $(0.0066)$ & $(0.0064)$ \\
\hline-0.0068 & -0.0075 & $-0.010^{*}$ & $-0.012 * *$ \\
\hline$(0.0063)$ & $(0.0063)$ & $(0.0060)$ & $(0.0059)$ \\
\hline$-0.060 * * *$ & $-0.062 * * *$ & $-0.070 * * *$ & $-0.070^{* * *}$ \\
\hline$(0.010)$ & $(0.010)$ & $(0.010)$ & $(0.0097)$ \\
\hline-0.013 & -0.014 & $-0.019^{*}$ & -0.016 \\
\hline (0.011) & $(0.011)$ & $(0.011)$ & $(0.010)$ \\
\hline$-0.017 * * *$ & $-0.014 * *$ & -0.0036 & 0.0046 \\
\hline$(0.0061)$ & $(0.0061)$ & $(0.0059)$ & $(0.0057)$ \\
\hline-0.0055 & -0.0039 & -0.00024 & $0.0065^{*}$ \\
\hline \multirow[t]{23}{*}{$(0.0039)$} & $(0.0039)$ & $(0.0038)$ & $(0.0037)$ \\
\hline & 0.000067 & 0.000025 & -0.000020 \\
\hline & $(0.00014)$ & $(0.00013)$ & $(0.00013)$ \\
\hline & $-0.0073 * * *$ & $-0.0043 * * *$ & $-0.0028 * *$ \\
\hline & $(0.0014)$ & $(0.0014)$ & $(0.0013)$ \\
\hline & 0.0030 & -0.00048 & 0.0017 \\
\hline & $(0.0068)$ & $(0.0066)$ & $(0.0064)$ \\
\hline & 0.0087 & 0.0065 & 0.0094 \\
\hline & $(0.0068)$ & $(0.0065)$ & $(0.0063)$ \\
\hline & $0.021 * * *$ & $0.018 * * *$ & $0.018^{* * *}$ \\
\hline & $(0.0060)$ & $(0.0058)$ & $(0.0056)$ \\
\hline & $-0.00038^{* * *}$ & $-0.00038^{* * *}$ & $-0.00039 * * *$ \\
\hline & $(0.00011)$ & $(0.00011)$ & $(0.00010)$ \\
\hline & $-0.085 * *$ & $-0.081 * *$ & $-0.095^{* * *}$ \\
\hline & $(0.038)$ & $(0.036)$ & $(0.035)$ \\
\hline & $-0.039 * *$ & -0.025 & -0.026 \\
\hline & $(0.017)$ & $(0.016)$ & $(0.016)$ \\
\hline & $-0.042 * *$ & -0.027 & -0.032 \\
\hline & $(0.021)$ & $(0.020)$ & $(0.020)$ \\
\hline & $-0.039 * *$ & -0.022 & -0.019 \\
\hline & $(0.016)$ & $(0.015)$ & $(0.015)$ \\
\hline & $-0.039 * *$ & -0.020 & -0.021 \\
\hline & $(0.018)$ & $(0.018)$ & $(0.017)$ \\
\hline
\end{tabular}


District of Columbia

Georgia

$-0.016$

$-0.0052$

$-0.021$

$(0.017)$

$(0.016)$

$-0.061$

$(0.038)$
$-0.055^{* *}$

$-0.049$

(0.037)

$-0.030$

(0.024)

$-0.041 * *$

$(0.016)$

$(0.023)$

$-0.028^{*}$

(0.016)

$-0.016$

$(0.017)$

$-0.051 * * *$

Iowa

Kansas

$(0.019)$

$-0.053^{* *}$

$-0.031 *$

$(0.018)$

$-0.036^{*}$

$-0.028$

$(0.020)$

$-0.015$

$(0.018)$

$(0.018)$

$-0.022$

$(0.021)$

$(0.020)$

$-0.028$

$(0.023)$

$(0.022)$

0.013

-0.023
$(0.019)$

$(0.018)$

$-0.018$

$-0.0070$

$(0.017)$
-0.015

$-0.040^{* *}$

$(0.016)$

$(0.017)$

(0.018)

-0.033
$(0.025)$

$(0.026)$

$-0.019$

(0.017) 
Nebraska

New Jersey

New York

North Carolina

$-0.028^{*}$

$(0.015)$

$-0.026$

$(0.016)$

-0.0013
$(0.032)$
-0.012

$-0.012$

0.0013

$0.016)$

$-0.026$

(0.024)

$-0.0093$

$-0.042^{* *}$

$(0.017)$
-0.026

$(0.033)$

$(0.016)$

$(0.015)$

$-0.042 * *$

$-0.039^{* *}$

Oklahoma

Oregon

Pennsylvania

Rhode Island

South Carolina

South Dakota

Tennessee

Texas

Utah

Vermont

$(0.019)$ 
West Virginia

National economy in the past year (ref. = gotten much better)

Stayed about the same

\section{Gotten worse}

Gotten much worse

\section{Not sure}

Household income in the past four years (ref. = increased a lot) Increased somewhat

Stayed about the same

\section{Decreased somewhat}

\section{Decreased a lot}

National economy in the next year will (ref. = get much better) Get somewhat better

Stay about the same

Get somewhat worse

Get much worse 
Political ideology (ref. = very liberal)

Liberal

Moderate

Conservative

Very conservative

Not sure

Constant

Observations

R-squared

Standard errors in parentheses

$* * * p<0.01, * * p<0.05, * p<0.1$

Sources: Authors' calculations from the Cooperative Congressional Election Study, 2016 and the American Community Survey, 2010-2014
$0.14^{* * *}$

(0.0056)

$0.23^{* * *}$

$(0.0063)$

$0.29 * * *$

$(0.0074)$

$0.17 * * *$

(0.0080)

$2.54 * * *$

$(0.30)$

$(0.010) \quad(0.24)$

$(0.30)$

$(0.32)$

$(0.31)$

37,402 0.477 
Table 3: Logistic regressions predicting Trump voting with conservative racial and immigration attitude scales: non-Hispanic White U.S. citizens

\begin{tabular}{|c|c|c|c|c|c|c|c|}
\hline \multirow[b]{3}{*}{ Variables } & \multicolumn{6}{|c|}{ General election } & \multirow{3}{*}{$\begin{array}{c}\text { Republican primary } \\
\begin{array}{c}\text { Trump vs. all } \\
\text { candidates }\end{array} \\
\end{array}$} \\
\hline & \multicolumn{3}{|c|}{ All states } & \multicolumn{3}{|c|}{ Swing states } & \\
\hline & $\begin{array}{l}\text { Trump vs. all } \\
\text { other including } \\
\text { non-voters }\end{array}$ & Trump vs. all candidates & $\begin{array}{l}\text { Trump vs. } \\
\text { Clinton }\end{array}$ & $\begin{array}{l}\text { Trump vs. all } \\
\text { other including } \\
\text { non-voters }\end{array}$ & $\begin{array}{c}\text { Trump vs. all } \\
\text { candidates }\end{array}$ & $\begin{array}{l}\text { Trump vs. } \\
\text { Clinton }\end{array}$ & \\
\hline Conservative racial attitude scale & $\begin{array}{c}0.68^{* * * *} \\
(0.028)\end{array}$ & $\begin{array}{l}0.81^{* * * *} \\
(0.033)\end{array}$ & $\begin{array}{l}1.04 * * * \\
(0.042)\end{array}$ & $\begin{array}{l}0.73 * * * \\
(0.046)\end{array}$ & $\begin{array}{l}0.82 * * * \\
(0.053)\end{array}$ & $\begin{array}{l}1.02 * * * \\
(0.066)\end{array}$ & $\begin{array}{c}0.28 * * * \\
(0.037)\end{array}$ \\
\hline Conservative immigration attitude scale & $\begin{array}{l}1.64 * * * \\
(0.058)\end{array}$ & $\begin{array}{l}1.96^{* * *} \\
(0.065)\end{array}$ & $\begin{array}{l}2.10^{* * * *} \\
(0.083)\end{array}$ & $\begin{array}{l}1.56^{* * *} \\
(0.094)\end{array}$ & $\begin{array}{c}1.90^{* * *} \\
(0.11)\end{array}$ & $\begin{array}{c}1.98^{* * * *} \\
(0.13)\end{array}$ & $\begin{array}{l}1.16^{* * *} \\
(0.086)\end{array}$ \\
\hline \multicolumn{8}{|l|}{ Vote 2012 general (ref. = Obama) } \\
\hline Romney & $\begin{array}{l}1.97 * * * \\
(0.046)\end{array}$ & $\begin{array}{c}2.09 * * * \\
(0.050)\end{array}$ & $\begin{array}{c}2.81 * * * \\
(0.063)\end{array}$ & $\begin{array}{c}2.00^{* * * *} \\
(0.073)\end{array}$ & $\begin{array}{c}2.16^{* * * *} \\
(0.081)\end{array}$ & $\begin{array}{c}2.79 * * * \\
(0.099)\end{array}$ & $\begin{array}{c}-0.51^{* * *} \\
(0.085)\end{array}$ \\
\hline Other & $\begin{array}{c}-0.17 * * * \\
(0.049)\end{array}$ & $\begin{array}{c}0.87 * * * \\
(0.056)\end{array}$ & $\begin{array}{l}1.38^{* * * *} \\
(0.068)\end{array}$ & $\begin{array}{c}-0.28^{* * * *} \\
(0.079)\end{array}$ & $\begin{array}{c}0.81 * * * \\
(0.091)\end{array}$ & $\begin{array}{c}1.31^{* * *} \\
(0.11)\end{array}$ & $\begin{array}{l}-0.16 \\
(0.11)\end{array}$ \\
\hline Pct. Romney vote 2012 general (county-level) & $\begin{array}{c}0.0086^{* * *} \\
(0.0024)\end{array}$ & $\begin{array}{l}0.011^{* * *} \\
(0.0028)\end{array}$ & $\begin{array}{c}0.013^{* * *} \\
(0.0035)\end{array}$ & $\begin{array}{c}0.0088^{* *} \\
(0.0040)\end{array}$ & $\begin{array}{c}0.0098^{* *} \\
(0.0046)\end{array}$ & $\begin{array}{c}0.0086 \\
(0.0057)\end{array}$ & $\begin{array}{c}-0.0052 \\
(0.0034)\end{array}$ \\
\hline Female & $\begin{array}{l}-0.066^{*} \\
(0.038)\end{array}$ & $\begin{array}{l}-0.039 \\
(0.044)\end{array}$ & $\begin{array}{c}-0.42^{* * * *} \\
(0.056)\end{array}$ & $\begin{array}{l}-0.060 \\
(0.062)\end{array}$ & $\begin{array}{l}-0.077 \\
(0.071)\end{array}$ & $\begin{array}{c}-0.43^{* * *} \\
(0.088)\end{array}$ & $\begin{array}{c}0.040 \\
(0.049)\end{array}$ \\
\hline Birth year & $\begin{array}{c}-0.0038^{* *} \\
(0.0019)\end{array}$ & $\begin{array}{l}-0.0021 \\
(0.0022)\end{array}$ & $\begin{array}{c}0.0075^{* * *} \\
(0.0028)\end{array}$ & $\begin{array}{l}-0.0020 \\
(0.0031)\end{array}$ & $\begin{array}{c}-0.00028 \\
(0.0036)\end{array}$ & $\begin{array}{l}0.0079^{*} \\
(0.0044)\end{array}$ & $\begin{array}{c}-0.0070^{* * * *} \\
(0.0026)\end{array}$ \\
\hline Child under 18 years & $\begin{array}{c}0.14 * * * \\
(0.048)\end{array}$ & $\begin{array}{c}0.21 * * * \\
(0.056)\end{array}$ & $\begin{array}{c}0.26^{* * *} \\
(0.072)\end{array}$ & $\begin{array}{c}0.14^{*} \\
(0.079)\end{array}$ & $\begin{array}{l}0.21^{* *} \\
(0.091)\end{array}$ & $\begin{array}{c}0.24 * * \\
(0.11)\end{array}$ & $\begin{array}{c}0.17^{* * * *} \\
(0.066)\end{array}$ \\
\hline \multicolumn{8}{|l|}{ Marital status $($ ref. $=$ married $)$} \\
\hline Separated & $\begin{array}{l}-0.23 \\
(0.15)\end{array}$ & $\begin{array}{l}-0.12 \\
(0.19)\end{array}$ & $\begin{array}{l}-0.072 \\
(0.24)\end{array}$ & $\begin{array}{l}-0.12 \\
(0.25)\end{array}$ & $\begin{array}{c}0.19 \\
(0.30)\end{array}$ & $\begin{array}{l}-0.059 \\
(0.36)\end{array}$ & $\begin{array}{l}0.035 \\
(0.25)\end{array}$ \\
\hline Divorced & $\begin{array}{l}-0.12^{* *} \\
(0.058)\end{array}$ & $\begin{array}{l}-0.074 \\
(0.068)\end{array}$ & $\begin{array}{l}-0.15^{*} \\
(0.088)\end{array}$ & $\begin{array}{l}-0.0034 \\
(0.095)\end{array}$ & $\begin{array}{l}0.078 \\
(0.11)\end{array}$ & $\begin{array}{l}0.0055 \\
(0.13)\end{array}$ & $\begin{array}{c}0.13 \\
(0.079)\end{array}$ \\
\hline Widowed & $\begin{array}{c}0.024 \\
(0.076)\end{array}$ & $\begin{array}{l}-0.039 \\
(0.089)\end{array}$ & $\begin{array}{l}0.043 \\
(0.11)\end{array}$ & $\begin{array}{l}0.091 \\
(0.13)\end{array}$ & $\begin{array}{l}-0.028 \\
(0.14)\end{array}$ & $\begin{array}{c}0.12 \\
(0.18)\end{array}$ & $\begin{array}{l}0.0057 \\
(0.098)\end{array}$ \\
\hline Single & $\begin{array}{c}-0.19^{* * * *} \\
(0.057)\end{array}$ & $\begin{array}{c}-0.21^{* * * *} \\
(0.066)\end{array}$ & $\begin{array}{c}-0.38^{* * * *} \\
(0.083)\end{array}$ & $\begin{array}{l}-0.088 \\
(0.094)\end{array}$ & $\begin{array}{l}-0.13 \\
(0.11)\end{array}$ & $\begin{array}{c}-0.28 * * \\
(0.13)\end{array}$ & $\begin{array}{c}0.062 \\
(0.084)\end{array}$ \\
\hline Domestic partnership & $\begin{array}{c}-0.14 \\
(0.092)\end{array}$ & $\begin{array}{l}-0.044 \\
(0.11)\end{array}$ & $\begin{array}{l}-0.19 \\
(0.13)\end{array}$ & $\begin{array}{c}-0.0012 \\
(0.14)\end{array}$ & $\begin{array}{l}0.041 \\
(0.16)\end{array}$ & $\begin{array}{l}-0.100 \\
(0.19)\end{array}$ & $\begin{array}{c}0.31^{* *} \\
(0.15)\end{array}$ \\
\hline \multicolumn{8}{|l|}{ Nativity/immigrant generation (ref. = foreign-born citizen) } \\
\hline Second generation (at least 1 foreign-born parent) & $\begin{array}{l}-0.10 \\
(0.12)\end{array}$ & $\begin{array}{l}-0.19 \\
(0.14)\end{array}$ & $\begin{array}{l}0.0046 \\
(0.17)\end{array}$ & $\begin{array}{l}-0.092 \\
(0.22)\end{array}$ & $\begin{array}{l}-0.15 \\
(0.24)\end{array}$ & $\begin{array}{l}0.058 \\
(0.29)\end{array}$ & $\begin{array}{l}-0.36^{*} \\
(0.19)\end{array}$ \\
\hline Third generation (at least 1 foreign-born grandparent) & $\begin{array}{l}-0.15 \\
(0.10)\end{array}$ & $\begin{array}{c}-0.31^{* * * *} \\
(0.12)\end{array}$ & $\begin{array}{l}-0.14 \\
(0.14)\end{array}$ & $\begin{array}{l}-0.22 \\
(0.19)\end{array}$ & $\begin{array}{l}-0.25 \\
(0.21)\end{array}$ & $\begin{array}{l}-0.026 \\
(0.25)\end{array}$ & $\begin{array}{c}-0.45^{* * * *} \\
(0.17)\end{array}$ \\
\hline
\end{tabular}


Fourth generation+

Education (ref. = less than high school)

High school graduate

Some college

2-year

4-year

Post-grad

Family income (ref. $=$ less than $\$ 10,000)$ $\$ 10,000$ - $\$ 19,999$

$\$ 20,000$ - $\$ 29,999$

$\$ 30,000$ - $\$ 39,999$

$\$ 40,000$ - $\$ 49,999$

$\$ 50,000$ - \$59,999

$\$ 60,000$ - $\$ 69,999$

$\$ 70,000$ - $\$ 79,999$

$\$ 80,000$ - $\$ 99,999$

$\$ 100,000$ - \$119,999

$\$ 120,000$ - \$149,999

$\$ 150,000$ or greater

Prefer not to say

Employment status (ref. $=$ full-time) Part-time

\begin{tabular}{|c|c|c|c|c|c|c|}
\hline $\begin{array}{l}-0.18^{*} \\
(0.098)\end{array}$ & $\begin{array}{c}-0.31 * * * \\
(0.11)\end{array}$ & $\begin{array}{l}-0.071 \\
(0.14)\end{array}$ & $\begin{array}{c}-0.25 \\
(0.18)\end{array}$ & $\begin{array}{l}-0.23 \\
(0.21)\end{array}$ & $\begin{array}{l}0.080 \\
(0.24)\end{array}$ & $\begin{array}{c}-0.45^{* * *} \\
(0.16)\end{array}$ \\
\hline $\begin{array}{l}0.24 * * \\
(0.11)\end{array}$ & $\begin{array}{l}-0.015 \\
(0.16)\end{array}$ & $\begin{array}{l}0.042 \\
(0.20)\end{array}$ & $\begin{array}{c}0.21 \\
(0.19)\end{array}$ & $\begin{array}{l}0.044 \\
(0.25)\end{array}$ & $\begin{array}{r}-0.055 \\
(0.31)\end{array}$ & $\begin{array}{c}-0.0061 \\
(0.20)\end{array}$ \\
\hline $0.34 * * *$ & -0.15 & 0.059 & $0.48 * *$ & 0.11 & 0.15 & -0.28 \\
\hline$(0.12)$ & $(0.16)$ & $(0.20)$ & $(0.20)$ & $(0.26)$ & $(0.32)$ & $(0.20)$ \\
\hline $0.27 * *$ & $-0.27^{*}$ & -0.10 & $0.36^{*}$ & -0.085 & -0.067 & -0.32 \\
\hline$(0.12)$ & $(0.16)$ & $(0.21)$ & $(0.20)$ & $(0.26)$ & $(0.33)$ & $(0.20)$ \\
\hline 0.049 & $-0.56 * * *$ & -0.25 & 0.071 & -0.40 & -0.30 & $-0.74 * * *$ \\
\hline$(0.12)$ & $(0.16)$ & $(0.20)$ & $(0.20)$ & $(0.26)$ & $(0.32)$ & $(0.20)$ \\
\hline-0.13 & $-0.71 * * *$ & $-0.39^{*}$ & -0.00086 & $-0.45^{*}$ & -0.31 & $-0.93 * * *$ \\
\hline$(0.12)$ & $(0.17)$ & $(0.21)$ & $(0.21)$ & $(0.27)$ & $(0.34)$ & $(0.21)$ \\
\hline-0.065 & -0.15 & -0.19 & 0.24 & -0.019 & -0.19 & $0.41^{* *}$ \\
\hline$(0.11)$ & $(0.14)$ & $(0.18)$ & $(0.18)$ & $(0.22)$ & $(0.27)$ & $(0.20)$ \\
\hline 0.063 & -0.12 & -0.23 & 0.20 & -0.033 & -0.21 & 0.26 \\
\hline$(0.11)$ & $(0.14)$ & $(0.17)$ & $(0.17)$ & $(0.22)$ & $(0.26)$ & $(0.18)$ \\
\hline 0.13 & -0.049 & -0.0093 & $0.35^{* *}$ & 0.095 & 0.049 & 0.22 \\
\hline$(0.11)$ & $(0.14)$ & $(0.17)$ & $(0.18)$ & $(0.22)$ & $(0.26)$ & $(0.18)$ \\
\hline $0.22 * *$ & -0.061 & -0.068 & $0.38 * *$ & 0.0090 & -0.10 & 0.070 \\
\hline$(0.11)$ & $(0.14)$ & $(0.18)$ & $(0.18)$ & $(0.22)$ & $(0.27)$ & $(0.18)$ \\
\hline $0.26^{* *}$ & 0.034 & 0.051 & $0.43 * *$ & 0.080 & 0.12 & 0.079 \\
\hline$(0.11)$ & $(0.14)$ & $(0.18)$ & $(0.18)$ & $(0.22)$ & $(0.27)$ & $(0.18)$ \\
\hline $0.24 * *$ & 0.033 & -0.017 & $0.53 * * *$ & 0.28 & 0.077 & 0.17 \\
\hline$(0.12)$ & $(0.15)$ & $(0.19)$ & $(0.19)$ & $(0.23)$ & $(0.28)$ & $(0.19)$ \\
\hline $0.35^{* * *}$ & 0.072 & -0.020 & $0.42 * *$ & 0.082 & 0.0030 & -0.025 \\
\hline$(0.12)$ & $(0.15)$ & $(0.19)$ & $(0.20)$ & $(0.24)$ & $(0.28)$ & $(0.19)$ \\
\hline $0.53^{* * *}$ & $0.25^{*}$ & 0.19 & $0.67 * * *$ & 0.34 & 0.22 & 0.092 \\
\hline$(0.12)$ & $(0.15)$ & $(0.18)$ & $(0.19)$ & $(0.23)$ & $(0.28)$ & $(0.19)$ \\
\hline $0.35^{* * *}$ & 0.097 & 0.060 & $0.50 * *$ & 0.14 & -0.14 & 0.17 \\
\hline$(0.12)$ & $(0.15)$ & $(0.19)$ & $(0.21)$ & $(0.25)$ & $(0.30)$ & $(0.19)$ \\
\hline $0.46^{* * *}$ & 0.19 & 0.13 & $0.62 * * *$ & 0.24 & 0.31 & 0.21 \\
\hline$(0.13)$ & $(0.16)$ & $(0.20)$ & $(0.21)$ & $(0.25)$ & $(0.31)$ & $(0.19)$ \\
\hline $0.36^{* * *}$ & 0.028 & -0.16 & $0.69 * * *$ & 0.33 & 0.11 & 0.039 \\
\hline$(0.13)$ & $(0.16)$ & $(0.20)$ & $(0.23)$ & $(0.26)$ & $(0.32)$ & $(0.20)$ \\
\hline $0.24 * *$ & -0.087 & -0.12 & 0.30 & -0.077 & -0.20 & 0.00085 \\
\hline$(0.11)$ & $(0.14)$ & $(0.18)$ & $(0.18)$ & $(0.22)$ & $(0.27)$ & $(0.18)$ \\
\hline 0.027 & 0.043 & 0.022 & 0.028 & 0.071 & -0.061 & 0.10 \\
\hline
\end{tabular}




\begin{tabular}{|c|c|c|c|c|c|c|c|}
\hline \multirow{3}{*}{ Temporarily laid off } & $(0.061)$ & $(0.071)$ & $(0.089)$ & $(0.099)$ & $(0.11)$ & $(0.14)$ & $(0.081)$ \\
\hline & -0.18 & -0.33 & -0.36 & -0.18 & -0.12 & -0.15 & 0.52 \\
\hline & $(0.25)$ & $(0.29)$ & $(0.36)$ & $(0.43)$ & $(0.51)$ & $(0.60)$ & $(0.36)$ \\
\hline \multirow[t]{2}{*}{ Unemployed } & $-0.17^{*}$ & -0.050 & -0.20 & 0.074 & 0.11 & -0.16 & $0.22 *$ \\
\hline & $(0.088)$ & $(0.11)$ & $(0.14)$ & $(0.15)$ & $(0.17)$ & $(0.21)$ & $(0.13)$ \\
\hline \multirow[t]{2}{*}{ Retired } & -0.029 & -0.026 & -0.082 & 0.058 & 0.11 & -0.0083 & $0.18 * * *$ \\
\hline & $(0.058)$ & $(0.066)$ & $(0.086)$ & $(0.094)$ & $(0.11)$ & $(0.13)$ & $(0.070)$ \\
\hline \multirow[t]{2}{*}{ Permanently disabled } & -0.11 & -0.055 & $-0.25^{* *}$ & -0.13 & -0.064 & $-0.30^{*}$ & $0.39 * * *$ \\
\hline & $(0.075)$ & $(0.091)$ & $(0.11)$ & $(0.12)$ & $(0.14)$ & $(0.17)$ & $(0.11)$ \\
\hline \multirow[t]{2}{*}{ Homemaker } & $-0.27 * * *$ & $-0.28 * * *$ & $-0.34 * * *$ & -0.11 & -0.060 & -0.14 & -0.022 \\
\hline & $(0.068)$ & $(0.081)$ & $(0.11)$ & $(0.11)$ & $(0.13)$ & $(0.16)$ & $(0.097)$ \\
\hline \multirow[t]{2}{*}{ Student } & $0.27 * *$ & -0.11 & -0.28 & 0.088 & -0.30 & $-0.59 * *$ & $-0.45^{* *}$ \\
\hline & $(0.13)$ & $(0.14)$ & $(0.18)$ & $(0.21)$ & $(0.23)$ & $(0.28)$ & $(0.22)$ \\
\hline \multirow[t]{2}{*}{ Other } & -0.100 & -0.11 & -0.010 & -0.25 & -0.097 & -0.26 & 0.18 \\
\hline & $(0.13)$ & $(0.15)$ & $(0.21)$ & $(0.24)$ & $(0.28)$ & $(0.36)$ & $(0.16)$ \\
\hline \multicolumn{8}{|l|}{ Union membership (ref. = never) } \\
\hline \multirow{2}{*}{ Current } & 0.058 & -0.080 & -0.050 & 0.13 & 0.059 & 0.020 & 0.17 \\
\hline & $(0.072)$ & $(0.080)$ & $(0.098)$ & $(0.13)$ & $(0.14)$ & $(0.16)$ & $(0.10)$ \\
\hline \multirow[t]{2}{*}{ Former } & 0.015 & -0.022 & -0.037 & -0.089 & -0.13 & $-0.18^{*}$ & -0.029 \\
\hline & $(0.046)$ & $(0.053)$ & $(0.068)$ & $(0.074)$ & $(0.084)$ & $(0.10)$ & $(0.057)$ \\
\hline \multirow[t]{2}{*}{ Pct. non-Hispanic White '10-14 (county-level) } & $-0.0048 * *$ & $-0.0058 * *$ & -0.0016 & -0.0027 & -0.0023 & 0.0021 & 0.00024 \\
\hline & $(0.0020)$ & $(0.0023)$ & $(0.0029)$ & $(0.0033)$ & $(0.0038)$ & $(0.0046)$ & $(0.0029)$ \\
\hline \multirow[t]{2}{*}{ Logged population density '10-14 (county-level) } & $-0.047 * * *$ & $-0.067 * * *$ & $-0.073 * * *$ & $-0.083 * * *$ & $-0.12 * * *$ & $-0.15^{* * *}$ & -0.031 \\
\hline & $(0.017)$ & $(0.020)$ & $(0.026)$ & $(0.030)$ & $(0.035)$ & $(0.043)$ & $(0.023)$ \\
\hline \multicolumn{8}{|l|}{ Time at current residence (ref. $=$ less than 1 year) } \\
\hline \multirow[t]{2}{*}{$1-2$ years } & -0.11 & $-0.27 * * *$ & $-0.21 *$ & -0.16 & -0.22 & -0.0095 & -0.083 \\
\hline & $(0.079)$ & $(0.093)$ & $(0.12)$ & $(0.13)$ & $(0.15)$ & $(0.18)$ & $(0.13)$ \\
\hline \multirow[t]{2}{*}{$3-4$ years } & 0.055 & -0.11 & -0.14 & 0.11 & 0.024 & -0.0020 & 0.0047 \\
\hline & $(0.078)$ & $(0.091)$ & $(0.12)$ & $(0.13)$ & $(0.15)$ & $(0.18)$ & $(0.12)$ \\
\hline \multirow[t]{2}{*}{5 or more years } & 0.10 & -0.083 & -0.14 & 0.14 & 0.0012 & 0.031 & 0.059 \\
\hline & $(0.068)$ & $(0.081)$ & $(0.10)$ & $(0.11)$ & $(0.13)$ & $(0.16)$ & $(0.11)$ \\
\hline \multirow[t]{2}{*}{ Current city residence length in years } & 0.0010 & 0.0011 & -0.0010 & 0.00012 & 0.0011 & -0.0012 & $0.0033^{* *}$ \\
\hline & $(0.0012)$ & $(0.0014)$ & $(0.0018)$ & $(0.0020)$ & $(0.0024)$ & $(0.0029)$ & $(0.0016)$ \\
\hline \multicolumn{8}{|c|}{ State of residence $($ ref. $=$ Alabama, Colorado for swing states) } \\
\hline \multirow[t]{2}{*}{ Arizona } & 0.19 & 0.00045 & -0.11 & & & & $0.52 * * *$ \\
\hline & $(0.19)$ & $(0.24)$ & $(0.33)$ & & & & $(0.19)$ \\
\hline \multirow[t]{2}{*}{ Arkansas } & -0.14 & -0.18 & $-0.67^{*}$ & & & & -0.21 \\
\hline & $(0.23)$ & $(0.29)$ & $(0.40)$ & & & & $(0.24)$ \\
\hline \multirow[t]{2}{*}{ California } & 0.045 & -0.22 & 0.0052 & & & & \\
\hline & $(0.18)$ & $(0.22)$ & $(0.30)$ & & & & \\
\hline
\end{tabular}




\begin{tabular}{|c|c|c|c|c|c|c|c|}
\hline Colorado & $\begin{array}{c}0.14 \\
(0.21)\end{array}$ & $\begin{array}{c}-0.29 \\
(0.25)\end{array}$ & $\begin{array}{l}-0.43 \\
(0.35)\end{array}$ & & & & $\begin{array}{c}0.27 \\
(0.26)\end{array}$ \\
\hline \multirow{2}{*}{ Connecticut } & 0.24 & 0.044 & -0.097 & & & & 0.44 \\
\hline & $(0.23)$ & $(0.27)$ & $(0.36)$ & & & & $(0.28)$ \\
\hline \multirow[t]{2}{*}{ Delaware } & 0.49 & 0.20 & 0.035 & & & & 0.47 \\
\hline & $(0.30)$ & $(0.35)$ & $(0.44)$ & & & & $(0.43)$ \\
\hline \multirow[t]{2}{*}{ District of Columbia } & -0.92 & $-1.36 * *$ & -0.54 & & & & -0.12 \\
\hline & $(0.59)$ & $(0.61)$ & $(0.78)$ & & & & $(0.92)$ \\
\hline \multirow{2}{*}{ Florida } & $0.33^{*}$ & 0.072 & -0.23 & 0.24 & $0.47 * * *$ & 0.32 & $0.38^{* *}$ \\
\hline & $(0.17)$ & $(0.21)$ & $(0.30)$ & $(0.16)$ & $(0.18)$ & $(0.23)$ & $(0.17)$ \\
\hline \multirow[t]{2}{*}{ Georgia } & $0.42 * *$ & 0.31 & 0.25 & & & & -0.0019 \\
\hline & $(0.19)$ & $(0.24)$ & $(0.33)$ & & & & $(0.18)$ \\
\hline \multirow[t]{2}{*}{ Hawaii } & 0.45 & 0.059 & 0.25 & & & & 0.12 \\
\hline & $(0.42)$ & $(0.49)$ & $(0.65)$ & & & & $(0.54)$ \\
\hline \multirow{2}{*}{ Idaho } & $-0.50 *$ & $-1.04 * * *$ & -0.18 & & & & -0.23 \\
\hline & $(0.27)$ & $(0.31)$ & $(0.45)$ & & & & $(0.29)$ \\
\hline \multirow[t]{2}{*}{ Illinois } & 0.072 & -0.16 & -0.27 & & & & -0.028 \\
\hline & $(0.19)$ & $(0.23)$ & $(0.31)$ & & & & $(0.19)$ \\
\hline \multirow[t]{2}{*}{ Indiana } & 0.23 & 0.050 & -0.14 & & & & 0.28 \\
\hline & $(0.19)$ & $(0.24)$ & $(0.33)$ & & & & $(0.20)$ \\
\hline \multirow[t]{2}{*}{ Iowa } & -0.044 & $-0.51^{*}$ & -0.51 & -0.26 & -0.33 & -0.22 & $-0.88^{* * *}$ \\
\hline & $(0.23)$ & $(0.27)$ & $(0.37)$ & $(0.22)$ & $(0.24)$ & $(0.31)$ & $(0.29)$ \\
\hline \multirow[t]{2}{*}{ Kansas } & 0.14 & -0.29 & -0.26 & & & & $-0.54^{*}$ \\
\hline & $(0.24)$ & $(0.29)$ & $(0.39)$ & & & & $(0.30)$ \\
\hline \multirow[t]{2}{*}{ Kentucky } & 0.23 & -0.095 & -0.47 & & & & -0.13 \\
\hline & $(0.20)$ & $(0.25)$ & $(0.34)$ & & & & $(0.23)$ \\
\hline \multirow[t]{2}{*}{ Louisiana } & 0.30 & 0.056 & -0.019 & & & & 0.36 \\
\hline & $(0.23)$ & $(0.29)$ & $(0.39)$ & & & & $(0.24)$ \\
\hline \multirow[t]{2}{*}{ Maine } & 0.11 & -0.23 & -0.19 & & & & -0.27 \\
\hline & $(0.27)$ & $(0.31)$ & $(0.42)$ & & & & $(0.41)$ \\
\hline \multirow[t]{2}{*}{ Maryland } & 0.035 & 0.0090 & 0.24 & & & & 0.26 \\
\hline & $(0.21)$ & $(0.26)$ & $(0.35)$ & & & & $(0.23)$ \\
\hline \multirow[t]{2}{*}{ Massachusetts } & -0.20 & $-0.48^{*}$ & -0.54 & & & & 0.094 \\
\hline & $(0.21)$ & $(0.25)$ & $(0.34)$ & & & & $(0.23)$ \\
\hline \multirow[t]{2}{*}{ Michigan } & 0.28 & 0.064 & -0.024 & 0.15 & $0.36^{*}$ & 0.40 & -0.19 \\
\hline & $(0.19)$ & $(0.23)$ & $(0.32)$ & $(0.17)$ & $(0.19)$ & $(0.24)$ & $(0.20)$ \\
\hline \multirow[t]{2}{*}{ Minnesota } & 0.28 & 0.023 & -0.32 & 0.11 & 0.28 & 0.063 & -0.39 \\
\hline & $(0.21)$ & $(0.25)$ & $(0.34)$ & $(0.20)$ & $(0.22)$ & $(0.28)$ & $(0.26)$ \\
\hline \multirow[t]{2}{*}{ Mississippi } & -0.26 & -0.18 & -0.18 & & & & 0.36 \\
\hline & $(0.28)$ & $(0.37)$ & $(0.53)$ & & & & $(0.28)$ \\
\hline
\end{tabular}




\begin{tabular}{|c|c|c|c|c|c|c|c|}
\hline Missouri & $\begin{array}{c}0.11 \\
(0.20)\end{array}$ & $\begin{array}{c}-0.36 \\
(0.24)\end{array}$ & $\begin{array}{l}-0.41 \\
(0.33)\end{array}$ & & & & $\begin{array}{c}0.12 \\
(0.20)\end{array}$ \\
\hline \multirow[t]{2}{*}{ Montana } & 0.38 & -0.25 & -0.071 & & & & \\
\hline & $(0.33)$ & $(0.37)$ & $(0.49)$ & & & & \\
\hline \multirow[t]{2}{*}{ Nebraska } & 0.033 & -0.14 & -0.39 & & & & \\
\hline & $(0.25)$ & $(0.30)$ & $(0.42)$ & & & & \\
\hline \multirow[t]{2}{*}{ Nevada } & 0.20 & -0.055 & -0.15 & 0.075 & 0.26 & 0.26 & 0.44 \\
\hline & $(0.23)$ & $(0.27)$ & $(0.36)$ & $(0.23)$ & $(0.25)$ & $(0.31)$ & $(0.28)$ \\
\hline \multirow[t]{2}{*}{ New Hampshire } & -0.037 & -0.30 & $-0.70^{*}$ & -0.22 & -0.079 & -0.39 & $-0.54 *$ \\
\hline & $(0.27)$ & $(0.31)$ & $(0.41)$ & $(0.26)$ & $(0.28)$ & $(0.36)$ & $(0.30)$ \\
\hline \multirow[t]{2}{*}{ New Jersey } & $0.34^{*}$ & 0.24 & 0.20 & & & & \\
\hline & $(0.19)$ & $(0.23)$ & $(0.32)$ & & & & \\
\hline \multirow[t]{2}{*}{ New Mexico } & -0.35 & $-0.69 * *$ & -0.52 & & & & \\
\hline & $(0.30)$ & $(0.35)$ & $(0.48)$ & & & & \\
\hline \multirow[t]{2}{*}{ New York } & $0.39 * *$ & 0.33 & 0.27 & & & & $0.65^{* * *}$ \\
\hline & $(0.18)$ & $(0.22)$ & $(0.31)$ & & & & $(0.20)$ \\
\hline \multirow[t]{2}{*}{ North Carolina } & 0.24 & -0.012 & -0.16 & 0.095 & 0.30 & 0.31 & -0.13 \\
\hline & $(0.19)$ & $(0.23)$ & $(0.32)$ & $(0.18)$ & $(0.20)$ & $(0.25)$ & $(0.18)$ \\
\hline \multirow{2}{*}{ North Dakota } & $-0.60 *$ & $-1.18 * * *$ & $-1.27 * *$ & & & & 0.29 \\
\hline & $(0.36)$ & $(0.42)$ & $(0.57)$ & & & & $(0.49)$ \\
\hline \multirow[t]{2}{*}{ Ohio } & 0.26 & 0.039 & -0.26 & 0.13 & $0.35^{*}$ & 0.19 & -0.25 \\
\hline & $(0.18)$ & $(0.23)$ & $(0.31)$ & $(0.17)$ & $(0.19)$ & $(0.24)$ & $(0.19)$ \\
\hline \multirow[t]{2}{*}{ Oklahoma } & -0.17 & -0.40 & $-0.84 * *$ & & & & -0.25 \\
\hline & $(0.22)$ & $(0.28)$ & $(0.38)$ & & & & $(0.25)$ \\
\hline \multirow{2}{*}{ Oregon } & 0.26 & -0.080 & -0.089 & & & & \\
\hline & $(0.22)$ & $(0.26)$ & $(0.36)$ & & & & \\
\hline \multirow[t]{2}{*}{ Pennsylvania } & $0.30^{*}$ & 0.18 & -0.094 & 0.17 & $0.49^{* * *}$ & 0.34 & $0.42 * *$ \\
\hline & $(0.18)$ & $(0.22)$ & $(0.31)$ & $(0.17)$ & $(0.18)$ & $(0.23)$ & $(0.19)$ \\
\hline \multirow[t]{2}{*}{ Rhode Island } & 0.24 & 0.027 & 0.043 & & & & $0.89 * *$ \\
\hline & $(0.32)$ & $(0.37)$ & $(0.47)$ & & & & $(0.41)$ \\
\hline \multirow[t]{2}{*}{ South Carolina } & $0.40^{*}$ & $0.51^{*}$ & $0.63^{*}$ & & & & -0.13 \\
\hline & $(0.21)$ & $(0.27)$ & $(0.37)$ & & & & $(0.21)$ \\
\hline \multirow[t]{2}{*}{ South Dakota } & 0.21 & -0.027 & -0.020 & & & & \\
\hline & $(0.32)$ & $(0.38)$ & $(0.52)$ & & & & \\
\hline \multirow[t]{2}{*}{ Tennessee } & 0.11 & -0.100 & -0.35 & & & & 0.14 \\
\hline & $(0.19)$ & $(0.24)$ & $(0.34)$ & & & & $(0.20)$ \\
\hline \multirow[t]{2}{*}{ Texas } & 0.0025 & -0.026 & -0.12 & & & & $-0.54 * * *$ \\
\hline & $(0.18)$ & $(0.22)$ & $(0.31)$ & & & & $(0.17)$ \\
\hline \multirow[t]{2}{*}{ Utah } & $-1.01 * * *$ & $-1.56^{* * *}$ & $-0.68^{*}$ & & & & -0.25 \\
\hline & $(0.23)$ & $(0.26)$ & $(0.41)$ & & & & $(0.28)$ \\
\hline
\end{tabular}




\begin{tabular}{|c|c|c|c|c|c|c|c|}
\hline Vermont & $\begin{array}{l}-0.19 \\
(0.39)\end{array}$ & $\begin{array}{l}-0.32 \\
(0.45)\end{array}$ & $\begin{array}{c}0.33 \\
(0.60)\end{array}$ & & & & $\begin{array}{l}-0.43 \\
(0.53)\end{array}$ \\
\hline Virginia & $\begin{array}{l}0.016 \\
(0.19)\end{array}$ & $\begin{array}{l}-0.26 \\
(0.23)\end{array}$ & $\begin{array}{l}-0.30 \\
(0.32)\end{array}$ & $\begin{array}{l}-0.11 \\
(0.18)\end{array}$ & $\begin{array}{l}0.091 \\
(0.20)\end{array}$ & $\begin{array}{c}0.20 \\
(0.26)\end{array}$ & $\begin{array}{l}-0.17 \\
(0.19)\end{array}$ \\
\hline Washington & $\begin{array}{c}0.25 \\
(0.21)\end{array}$ & $\begin{array}{l}-0.080 \\
(0.24)\end{array}$ & $\begin{array}{c}0.14 \\
(0.34)\end{array}$ & & & & \\
\hline West Virginia & $\begin{array}{l}-0.14 \\
(0.23)\end{array}$ & $\begin{array}{l}-0.34 \\
(0.30)\end{array}$ & $\begin{array}{c}-0.68^{*} \\
(0.40)\end{array}$ & & & & \\
\hline Wisconsin & $\begin{array}{l}0.093 \\
(0.20)\end{array}$ & $\begin{array}{l}-0.042 \\
(0.24)\end{array}$ & $\begin{array}{l}-0.10 \\
(0.33)\end{array}$ & $\begin{array}{l}-0.065 \\
(0.19)\end{array}$ & $\begin{array}{c}0.21 \\
(0.21)\end{array}$ & $\begin{array}{c}0.25 \\
(0.27)\end{array}$ & $\begin{array}{l}-0.22 \\
(0.21)\end{array}$ \\
\hline Wyoming & $\begin{array}{c}-1.07 * * \\
(0.44)\end{array}$ & $\begin{array}{l}-1.27 * * \\
(0.53)\end{array}$ & $\begin{array}{l}-1.44 * \\
(0.77)\end{array}$ & & & & $\begin{array}{c}0.24 \\
(0.50)\end{array}$ \\
\hline \multicolumn{8}{|c|}{ National economy in the past year (ref. = gotten much better) } \\
\hline Gotten better & $\begin{array}{c}-0.35^{* *} \\
(0.13)\end{array}$ & $\begin{array}{c}-0.34^{* *} \\
(0.15)\end{array}$ & $\begin{array}{l}-0.19 \\
(0.16)\end{array}$ & $\begin{array}{l}0.024 \\
(0.23)\end{array}$ & $\begin{array}{c}-0.0090 \\
(0.25)\end{array}$ & $\begin{array}{l}-0.014 \\
(0.27)\end{array}$ & $\begin{array}{c}-1.10^{* * * *} \\
(0.28)\end{array}$ \\
\hline Stayed about the same & $\begin{array}{c}0.63 * * * \\
(0.13)\end{array}$ & $\begin{array}{c}0.62^{* * * *} \\
(0.15)\end{array}$ & $\begin{array}{c}0.87^{* * * *} \\
(0.17)\end{array}$ & $\begin{array}{c}1.11^{* * * *} \\
(0.23)\end{array}$ & $\begin{array}{c}1.07^{* * * *} \\
(0.25)\end{array}$ & $\begin{array}{c}1.18 * * * \\
(0.27)\end{array}$ & $\begin{array}{c}-0.74 * * * \\
(0.28)\end{array}$ \\
\hline Gotten worse & $\begin{array}{c}1.34^{* * *} \\
(0.14)\end{array}$ & $\begin{array}{c}1.50^{* * *} \\
(0.15)\end{array}$ & $\begin{array}{c}1.92 * * * \\
(0.17)\end{array}$ & $\begin{array}{c}1.88^{* * *} \\
(0.24)\end{array}$ & $\begin{array}{c}2.01 * * * \\
(0.26)\end{array}$ & $\begin{array}{c}2.32 * * * \\
(0.28)\end{array}$ & $\begin{array}{l}-0.26 \\
(0.28)\end{array}$ \\
\hline Gotten much worse & $\begin{array}{c}1.60^{* * *} \\
(0.15)\end{array}$ & $\begin{array}{c}1.94 * * * \\
(0.17)\end{array}$ & $\begin{array}{c}2.40 * * * \\
(0.20)\end{array}$ & $\begin{array}{c}2.26^{* * *} \\
(0.25)\end{array}$ & $\begin{array}{c}2.47 * * * \\
(0.28)\end{array}$ & $\begin{array}{c}2.76^{* * * *} \\
(0.32)\end{array}$ & $\begin{array}{c}0.17 \\
(0.28)\end{array}$ \\
\hline Not sure & $\begin{array}{l}0.34 * * \\
(0.17)\end{array}$ & $\begin{array}{l}0.38^{* *} \\
(0.19)\end{array}$ & $\begin{array}{c}0.79 * * * \\
(0.23)\end{array}$ & $\begin{array}{c}0.92 * * * \\
(0.29)\end{array}$ & $\begin{array}{c}0.92 * * * \\
(0.32)\end{array}$ & $\begin{array}{c}1.22 * * * \\
(0.36)\end{array}$ & $\begin{array}{l}-0.58^{*} \\
(0.35)\end{array}$ \\
\hline \multicolumn{8}{|c|}{ Household income in the past four years (ref. = increased a lot) } \\
\hline Increased somewhat & $\begin{array}{l}0.0072 \\
(0.094)\end{array}$ & $\begin{array}{l}0.042 \\
(0.10)\end{array}$ & $\begin{array}{l}-0.028 \\
(0.13)\end{array}$ & $\begin{array}{l}-0.053 \\
(0.16)\end{array}$ & $\begin{array}{l}0.058 \\
(0.17)\end{array}$ & $\begin{array}{l}0.059 \\
(0.21)\end{array}$ & $\begin{array}{l}0.32^{*} \\
(0.17)\end{array}$ \\
\hline Stayed about the same & $\begin{array}{l}0.21 * * \\
(0.095)\end{array}$ & $\begin{array}{l}0.22 * * \\
(0.11)\end{array}$ & $\begin{array}{l}0.082 \\
(0.13)\end{array}$ & $\begin{array}{c}0.16 \\
(0.16)\end{array}$ & $\begin{array}{c}0.25 \\
(0.18)\end{array}$ & $\begin{array}{c}0.24 \\
(0.21)\end{array}$ & $\begin{array}{l}0.38^{* *} \\
(0.17)\end{array}$ \\
\hline Decreased somewhat & $\begin{array}{c}0.33 * * * \\
(0.10)\end{array}$ & $\begin{array}{c}0.38^{* * *} \\
(0.11)\end{array}$ & $\begin{array}{l}0.25^{*} \\
(0.14)\end{array}$ & $\begin{array}{c}0.16 \\
(0.17)\end{array}$ & $\begin{array}{c}0.27 \\
(0.19)\end{array}$ & $\begin{array}{c}0.26 \\
(0.23)\end{array}$ & $\begin{array}{l}0.33^{*} \\
(0.17)\end{array}$ \\
\hline Decreased a lot & $\begin{array}{c}0.30^{* * *} \\
(0.11)\end{array}$ & $\begin{array}{l}0.31^{* *} \\
(0.13)\end{array}$ & $\begin{array}{c}0.26 \\
(0.16)\end{array}$ & $\begin{array}{c}0.25 \\
(0.18)\end{array}$ & $\begin{array}{c}0.31 \\
(0.21)\end{array}$ & $\begin{array}{c}0.31 \\
(0.25)\end{array}$ & $\begin{array}{c}0.28 \\
(0.18)\end{array}$ \\
\hline \multicolumn{8}{|c|}{ National economy in the next year will (ref. = get much better) } \\
\hline Get somewhat better & $\begin{array}{c}-0.59 * * * \\
(0.13)\end{array}$ & $\begin{array}{c}-0.68 * * * \\
(0.14)\end{array}$ & $\begin{array}{c}-0.47 * * * \\
(0.16)\end{array}$ & $\begin{array}{c}-0.88^{* * *} \\
(0.21)\end{array}$ & $\begin{array}{c}-0.91 * * * \\
(0.23)\end{array}$ & $\begin{array}{c}-0.71 * * * \\
(0.25)\end{array}$ & $\begin{array}{c}-0.90^{* * * *} \\
(0.25)\end{array}$ \\
\hline Stay about the same & $\begin{array}{c}-0.95^{* * *} \\
(0.13)\end{array}$ & $\begin{array}{c}-1.04 * * * \\
(0.14)\end{array}$ & $\begin{array}{c}-0.62 * * * \\
(0.16)\end{array}$ & $\begin{array}{c}-1.11^{* * * *} \\
(0.21)\end{array}$ & $\begin{array}{c}-1.20 * * * \\
(0.23)\end{array}$ & $\begin{array}{c}-0.84 * * * \\
(0.25)\end{array}$ & $\begin{array}{c}-1.42 * * * \\
(0.25)\end{array}$ \\
\hline Get somewhat worse & $\begin{array}{c}-0.92 * * * \\
(0.13)\end{array}$ & $\begin{array}{c}-1.01 * * * \\
(0.15)\end{array}$ & $\begin{array}{c}-0.32^{*} \\
(0.17)\end{array}$ & $\begin{array}{c}-1.05^{* * *} \\
(0.21)\end{array}$ & $\begin{array}{c}-1.11^{* * *} \\
(0.24)\end{array}$ & $\begin{array}{l}-0.47^{*} \\
(0.27)\end{array}$ & $\begin{array}{c}-1.62^{* * * *} \\
(0.25)\end{array}$ \\
\hline Get much worse & $-1.27 * * *$ & $-1.50 * * *$ & $-0.51 * * *$ & $-1.61 * * *$ & $-1.82 * * *$ & $-0.96 * * *$ & $-1.68^{* * * *}$ \\
\hline
\end{tabular}




\begin{tabular}{|c|c|c|c|c|c|c|c|}
\hline \multirow{3}{*}{ Not sure } & $(0.14)$ & $(0.16)$ & $(0.20)$ & $(0.23)$ & $(0.26)$ & $(0.30)$ & $(0.26)$ \\
\hline & $-0.53 * * *$ & $-0.62 * * *$ & -0.22 & $-0.67 * * *$ & $-0.82 * * *$ & $-0.45^{*}$ & $-1.36^{* * *}$ \\
\hline & $(0.13)$ & $(0.15)$ & $(0.17)$ & $(0.21)$ & $(0.24)$ & $(0.26)$ & $(0.25)$ \\
\hline \multicolumn{8}{|c|}{ Political ideology (ref. = very liberal) } \\
\hline Liberal & $0.37^{* * *}$ & $0.34^{* *}$ & $0.34^{* *}$ & 0.24 & 0.21 & 0.15 & -0.18 \\
\hline \multirow{2}{*}{ Moderate } & $\begin{array}{c}(0.13) \\
1.20^{* * *}\end{array}$ & $\begin{array}{c}(0.14) \\
1.18^{* * *}\end{array}$ & $\begin{array}{c}(0.15) \\
1.29 * * *\end{array}$ & $\begin{array}{c}(0.21) \\
1.12^{* * *}\end{array}$ & $\begin{array}{c}(0.22) \\
1.14 * * *\end{array}$ & $\begin{array}{c}(0.23) \\
1.17 * * *\end{array}$ & $\begin{array}{l}(0.34) \\
-0.24\end{array}$ \\
\hline & $(0.12)$ & $(0.13)$ & $(0.14)$ & $(0.19)$ & $(0.20)$ & $(0.22)$ & $(0.31)$ \\
\hline \multirow[t]{2}{*}{ Conservative } & $2.02 * * *$ & $2.13 * * *$ & $2.46^{* * *}$ & $1.90^{* * *}$ & $2.01 * * *$ & $2.21 * * *$ & -0.39 \\
\hline & $(0.12)$ & $(0.13)$ & $(0.15)$ & $(0.19)$ & $(0.21)$ & $(0.23)$ & $(0.31)$ \\
\hline \multirow[t]{2}{*}{ Very conservative } & $1.99 * * *$ & $2.17 * * *$ & $2.92 * * *$ & $2.10^{* * *}$ & $2.28 * * *$ & $2.79 * * *$ & $-1.03 * * *$ \\
\hline & $(0.13)$ & $(0.15)$ & $(0.19)$ & $(0.21)$ & $(0.24)$ & $(0.30)$ & $(0.32)$ \\
\hline \multirow[t]{2}{*}{ Not sure } & $0.57 * * *$ & $1.15^{* * *}$ & $1.29 * * *$ & 0.34 & $1.03 * * *$ & $1.07 * * *$ & 0.034 \\
\hline & $(0.14)$ & $(0.15)$ & $(0.17)$ & $(0.21)$ & $(0.24)$ & $(0.26)$ & $(0.36)$ \\
\hline \multirow[t]{2}{*}{ Constant } & 2.15 & -0.32 & $-20.4 * * *$ & -1.67 & -4.70 & $-21.6 * *$ & $15.1 * * *$ \\
\hline & (3.74) & (4.33) & $(5.52)$ & $(6.21)$ & (7.13) & $(8.72)$ & $(5.12)$ \\
\hline Observations & 37,134 & 32,630 & 29,631 & 14,104 & 12,454 & 11,451 & 10,270 \\
\hline
\end{tabular}

Standard errors in parentheses

Standard errors in parentheses
$* * *$
$\mathrm{p}<0.01, * * \mathrm{p}<0.05, * \mathrm{p}<0.1$

Sources: Authors' calculations from the Cooperative Congressional Election Study, 2016, the American Community Survey, 2010-2014, and Election Atlas.

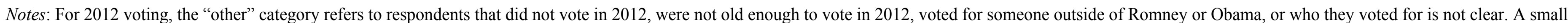
number of respondents that were not old enough to vote in 2012 claim to have voted for Obama or Romney, so we code them as having voted for one of these candidates in order to capture their preference. 
Figure 8: Marginal changes in the percentage voting for Donald Trump in 2016 at the 25th and 75th percentiles of conservative racial and immigration attitudes: non-Hispanic White voters

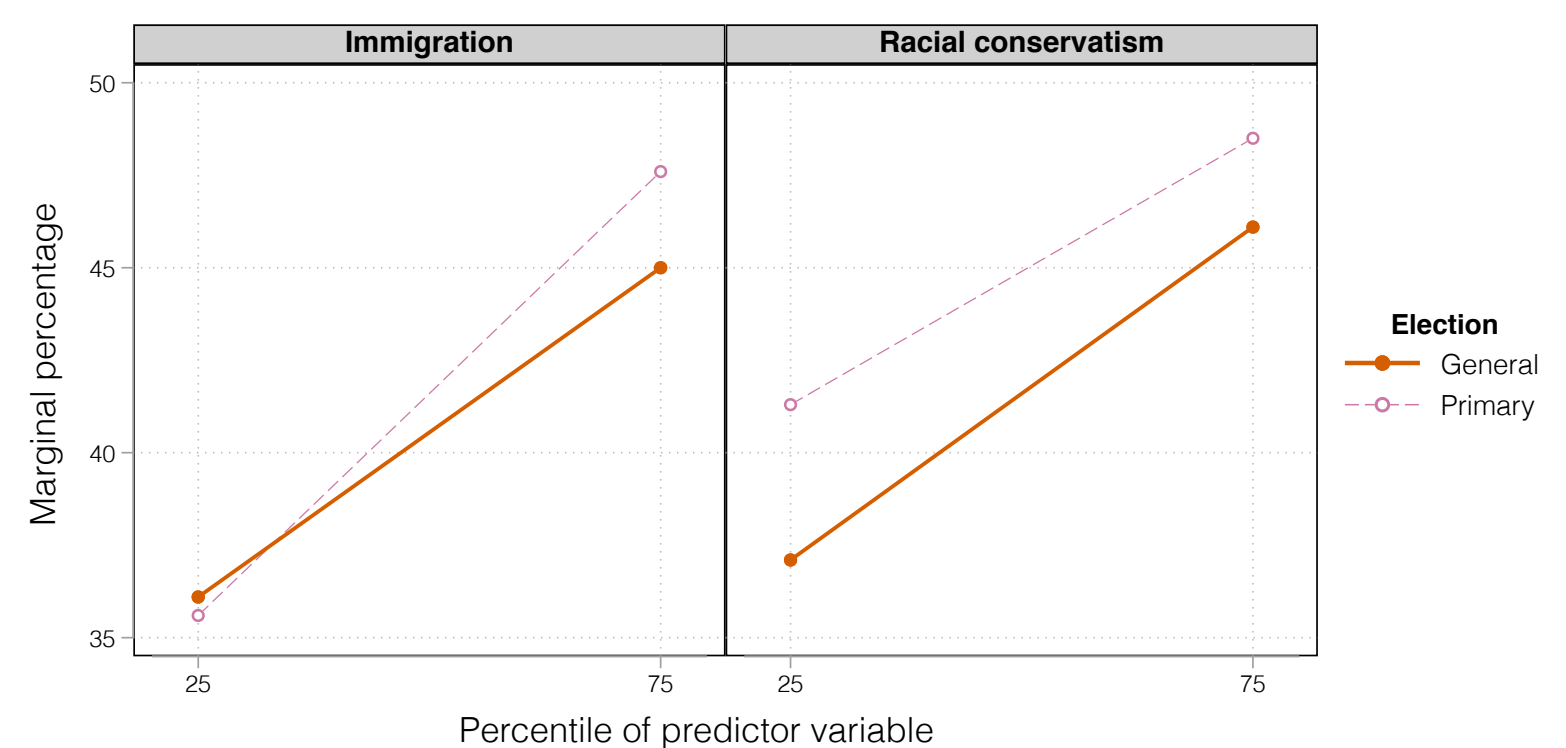

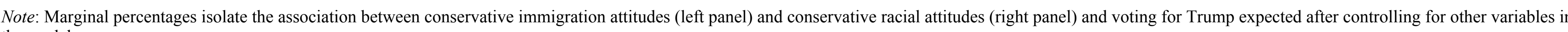
the model.

Source: Authors' calculations from the Cooperative Congressional Election Study, 2016. 


\begin{tabular}{|c|c|c|c|c|c|c|c|}
\hline \multirow[b]{3}{*}{ Variables } & \multicolumn{6}{|c|}{ General election } & \multirow{3}{*}{$\begin{array}{c}\text { Republican primary } \\
\begin{array}{c}\text { Trump vs. all } \\
\text { candidates }\end{array} \\
\end{array}$} \\
\hline & \multicolumn{3}{|c|}{ All states } & \multicolumn{3}{|c|}{ Swing states } & \\
\hline & $\begin{array}{l}\text { Trump vs. all other } \\
\text { including non- } \\
\text { voters }\end{array}$ & $\begin{array}{l}\text { Trump vs. all } \\
\text { candidates }\end{array}$ & $\begin{array}{c}\text { Trump vs. } \\
\text { Clinton }\end{array}$ & $\begin{array}{c}\text { Trump vs. all } \\
\text { other including } \\
\text { non-voters } \\
\end{array}$ & $\begin{array}{l}\text { Trump vs. all } \\
\text { candidates }\end{array}$ & $\begin{array}{c}\text { Trump vs. } \\
\text { Clinton }\end{array}$ & \\
\hline \multirow[t]{2}{*}{ Whites have advantages } & $-0.29 * * *$ & $-0.34 * * *$ & $-0.39 * * *$ & $-0.27 * * *$ & $-0.31 * * *$ & $-0.38^{* * *}$ & $-0.15^{* * *}$ \\
\hline & $(0.015)$ & $(0.017)$ & $(0.022)$ & $(0.024)$ & $(0.028)$ & $(0.035)$ & $(0.021)$ \\
\hline \multirow{2}{*}{ Racial problems are rare/isolated } & $0.16^{* * *}$ & $0.16^{* * *}$ & $0.30^{* * *}$ & $0.22 * * *$ & $0.23 * * *$ & $0.31 * * *$ & $-0.064 * * *$ \\
\hline & $(0.016)$ & $(0.019)$ & $(0.025)$ & $(0.027)$ & $(0.031)$ & $(0.039)$ & $(0.020)$ \\
\hline \multirow[t]{2}{*}{ Fearful of other races } & $0.084 * * *$ & $0.12 * * *$ & 0.020 & $0.077 * * *$ & $0.11^{* * *}$ & 0.038 & $0.13^{* * *}$ \\
\hline & $(0.015)$ & $(0.018)$ & $(0.023)$ & $(0.025)$ & $(0.029)$ & $(0.036)$ & $(0.020)$ \\
\hline \multirow[t]{2}{*}{ Angry racism exists } & $-0.10 * * *$ & $-0.13 * * *$ & $-0.29 * * *$ & $-0.13 * * *$ & $-0.12 * * *$ & $-0.23 * * *$ & $-0.092 * * *$ \\
\hline & $(0.019)$ & $(0.023)$ & $(0.032)$ & $(0.032)$ & $(0.038)$ & $(0.049)$ & $(0.022)$ \\
\hline \multirow[t]{2}{*}{ Conservative immigration attitude scale } & $1.60^{* * *}$ & $1.91^{* * *}$ & $2.05^{* * *}$ & $1.54^{* * *}$ & $1.87^{* * *}$ & $1.95^{* * *}$ & $1.12^{* * *}$ \\
\hline & $(0.058)$ & $(0.066)$ & $(0.085)$ & $(0.095)$ & $(0.11)$ & $(0.13)$ & $(0.086)$ \\
\hline \multicolumn{8}{|l|}{ Vote 2012 general $($ ref. $=$ Obama $)$} \\
\hline \multirow[t]{2}{*}{ Romney } & $1.94 * * *$ & $2.06^{* * *}$ & $2.77 * * *$ & $1.97^{* * *}$ & $2.14^{* * *}$ & $2.75^{* * *}$ & $-0.49 * * *$ \\
\hline & $(0.046)$ & $(0.051)$ & $(0.064)$ & $(0.074)$ & $(0.081)$ & $(0.10)$ & $(0.086)$ \\
\hline \multirow{2}{*}{ Other } & $-0.19 * * *$ & $0.86^{* * *}$ & $1.37 * * *$ & $-0.31 * * *$ & $0.79 * * *$ & $1.30^{* * *}$ & -0.14 \\
\hline & $(0.050)$ & $(0.057)$ & $(0.069)$ & $(0.080)$ & $(0.092)$ & $(0.11)$ & $(0.11)$ \\
\hline \multirow[t]{2}{*}{ Pct. Romney vote 2012 general (county-level) } & $0.0084 * * *$ & $0.010^{* * *}$ & $0.013^{* * *}$ & $0.0085^{* *}$ & $0.0095 * *$ & 0.0083 & -0.0055 \\
\hline & $(0.0024)$ & $(0.0028)$ & $(0.0036)$ & $(0.0040)$ & $(0.0046)$ & $(0.0058)$ & $(0.0034)$ \\
\hline \multirow[t]{2}{*}{ Female } & $-0.079 * *$ & -0.056 & $-0.42 * * *$ & -0.070 & -0.091 & $-0.45 * * *$ & 0.013 \\
\hline & $(0.038)$ & $(0.044)$ & $(0.057)$ & $(0.063)$ & $(0.072)$ & $(0.090)$ & $(0.050)$ \\
\hline \multirow{2}{*}{ Birth year } & $-0.0040 * *$ & -0.0022 & $0.0068^{* *}$ & -0.0024 & -0.00083 & 0.0068 & $-0.0061 * *$ \\
\hline & $(0.0019)$ & $(0.0022)$ & $(0.0028)$ & $(0.0032)$ & $(0.0036)$ & $(0.0044)$ & $(0.0026)$ \\
\hline \multirow[t]{2}{*}{ Child under 18 years } & $0.14 * * *$ & $0.21^{* * *}$ & $0.25 * * *$ & 0.12 & $0.20^{* *}$ & $0.21^{*}$ & $0.17 * *$ \\
\hline & $(0.048)$ & $(0.056)$ & $(0.073)$ & $(0.080)$ & $(0.092)$ & $(0.11)$ & $(0.066)$ \\
\hline \multicolumn{8}{|l|}{ Marital status $($ ref. $=$ married $)$} \\
\hline \multirow[t]{2}{*}{ Separated } & -0.24 & -0.11 & -0.16 & -0.13 & 0.17 & -0.15 & 0.013 \\
\hline & $(0.15)$ & $(0.19)$ & $(0.24)$ & $(0.25)$ & $(0.30)$ & $(0.36)$ & $(0.25)$ \\
\hline \multirow[t]{2}{*}{ Divorced } & $-0.13^{* *}$ & -0.071 & $-0.16^{*}$ & -0.019 & 0.071 & -0.017 & $0.15^{*}$ \\
\hline & $(0.058)$ & $(0.069)$ & $(0.088)$ & $(0.096)$ & $(0.11)$ & $(0.14)$ & $(0.080)$ \\
\hline \multirow[t]{2}{*}{ Widowed } & 0.028 & -0.023 & 0.036 & 0.072 & -0.045 & 0.082 & 0.011 \\
\hline & $(0.076)$ & $(0.089)$ & $(0.11)$ & $(0.13)$ & $(0.14)$ & $(0.18)$ & $(0.099)$ \\
\hline \multirow[t]{2}{*}{ Single } & $-0.18 * * *$ & $-0.20 * * *$ & $-0.40 * * *$ & -0.084 & -0.12 & $-0.29^{* *}$ & 0.064 \\
\hline & $(0.057)$ & $(0.067)$ & $(0.084)$ & $(0.094)$ & $(0.11)$ & $(0.13)$ & $(0.085)$ \\
\hline Domestic partnership & -0.15 & -0.055 & $-0.23^{*}$ & -0.032 & 0.017 & -0.18 & $0.31 * *$ \\
\hline
\end{tabular}




\begin{tabular}{|c|c|c|c|c|c|c|c|}
\hline & $(0.092)$ & $(0.11)$ & $(0.13)$ & $(0.14)$ & $(0.16)$ & $(0.20)$ & $(0.15)$ \\
\hline \multicolumn{8}{|l|}{ Nativity/immigrant generation (ref. $=$ foreign-born citizen) } \\
\hline \multirow[t]{2}{*}{ Second generation (at least 1 foreign-born parent) } & -0.14 & -0.22 & -0.044 & -0.11 & -0.18 & 0.0052 & $-0.39 * *$ \\
\hline & $(0.12)$ & $(0.14)$ & $(0.17)$ & $(0.22)$ & $(0.25)$ & $(0.29)$ & $(0.19)$ \\
\hline \multirow[t]{2}{*}{ Third generation (at least 1 foreign-born grandparent) } & $-0.20^{*}$ & $-0.35^{* * *}$ & -0.23 & -0.23 & -0.29 & -0.10 & $-0.47 * * *$ \\
\hline & $(0.10)$ & $(0.12)$ & $(0.14)$ & $(0.19)$ & $(0.21)$ & $(0.25)$ & $(0.17)$ \\
\hline \multirow[t]{2}{*}{ Fourth generation +} & $-0.23 * *$ & $-0.35 * * *$ & -0.14 & -0.26 & -0.26 & 0.015 & $-0.47 * * *$ \\
\hline & $(0.099)$ & $(0.11)$ & $(0.14)$ & $(0.19)$ & $(0.21)$ & $(0.24)$ & $(0.17)$ \\
\hline \multicolumn{8}{|l|}{ Education (ref. $=$ less than high school) } \\
\hline \multirow[t]{2}{*}{ High school graduate } & $0.20^{*}$ & -0.022 & 0.012 & 0.21 & 0.046 & -0.064 & 0.047 \\
\hline & $(0.11)$ & $(0.16)$ & $(0.20)$ & $(0.19)$ & $(0.25)$ & $(0.32)$ & $(0.20)$ \\
\hline \multirow[t]{2}{*}{ Some college } & $0.31 * * *$ & -0.15 & 0.038 & $0.46^{* *}$ & 0.11 & 0.14 & -0.22 \\
\hline & $(0.12)$ & $(0.16)$ & $(0.20)$ & $(0.20)$ & $(0.26)$ & $(0.32)$ & $(0.20)$ \\
\hline \multirow[t]{2}{*}{ 2-year degree } & $0.24 * *$ & -0.27 & -0.13 & $0.35^{*}$ & -0.078 & -0.076 & -0.26 \\
\hline & $(0.12)$ & $(0.16)$ & $(0.21)$ & $(0.20)$ & $(0.27)$ & $(0.33)$ & $(0.20)$ \\
\hline \multirow[t]{2}{*}{ 4-year degree } & 0.051 & $-0.51^{* * *}$ & -0.24 & 0.092 & -0.36 & -0.27 & $-0.65^{* * *}$ \\
\hline & $(0.12)$ & $(0.16)$ & $(0.21)$ & $(0.20)$ & $(0.26)$ & $(0.33)$ & $(0.20)$ \\
\hline \multirow[t]{2}{*}{ Post-graduate degree } & -0.13 & $-0.66 * * *$ & $-0.39 *$ & -0.0070 & -0.43 & -0.32 & $-0.84 * * *$ \\
\hline & $(0.13)$ & $(0.17)$ & $(0.21)$ & $(0.21)$ & $(0.27)$ & $(0.34)$ & $(0.21)$ \\
\hline \multicolumn{8}{|l|}{ Family income $($ ref. $=$ less than $\$ 10,000)$} \\
\hline \multirow[t]{2}{*}{$\$ 10,000-\$ 19,999$} & -0.087 & -0.17 & -0.22 & 0.22 & -0.0045 & -0.18 & $0.44 * *$ \\
\hline & $(0.11)$ & $(0.15)$ & $(0.18)$ & $(0.18)$ & $(0.22)$ & $(0.27)$ & $(0.20)$ \\
\hline \multirow[t]{2}{*}{$\$ 20,000-\$ 29,999$} & 0.042 & -0.14 & -0.26 & 0.18 & -0.023 & -0.19 & 0.30 \\
\hline & $(0.11)$ & $(0.14)$ & $(0.17)$ & $(0.17)$ & $(0.22)$ & $(0.26)$ & $(0.19)$ \\
\hline \multirow[t]{2}{*}{$\$ 30,000-\$ 39,999$} & 0.098 & -0.070 & -0.043 & $0.32 *$ & 0.090 & 0.052 & 0.26 \\
\hline & $(0.11)$ & $(0.14)$ & $(0.18)$ & $(0.18)$ & $(0.22)$ & $(0.26)$ & $(0.18)$ \\
\hline \multirow[t]{2}{*}{$\$ 40,000-\$ 49,999$} & $0.20^{*}$ & -0.083 & -0.10 & $0.36^{* *}$ & 0.0078 & -0.088 & 0.11 \\
\hline & $(0.11)$ & $(0.14)$ & $(0.18)$ & $(0.18)$ & $(0.22)$ & $(0.27)$ & $(0.18)$ \\
\hline \multirow[t]{2}{*}{$\$ 50,000-\$ 59,999$} & $0.22 * *$ & 0.0061 & 0.0063 & $0.38^{* *}$ & 0.074 & 0.12 & 0.10 \\
\hline & $(0.11)$ & $(0.14)$ & $(0.18)$ & $(0.18)$ & $(0.22)$ & $(0.27)$ & $(0.19)$ \\
\hline \multirow[t]{2}{*}{$\$ 60,000-\$ 69,999$} & $0.20^{*}$ & 0.0047 & -0.080 & $0.49^{* *}$ & 0.28 & 0.071 & 0.21 \\
\hline & $(0.12)$ & $(0.15)$ & $(0.19)$ & $(0.19)$ & $(0.23)$ & $(0.28)$ & $(0.19)$ \\
\hline \multirow[t]{2}{*}{$\$ 70,000-\$ 79,999$} & $0.32 * * *$ & 0.035 & -0.079 & $0.37 *$ & 0.057 & -0.028 & 0.019 \\
\hline & $(0.12)$ & $(0.15)$ & $(0.19)$ & $(0.20)$ & $(0.24)$ & $(0.29)$ & $(0.19)$ \\
\hline \multirow[t]{2}{*}{$\$ 80,000-\$ 99,999$} & $0.50 * * *$ & 0.24 & 0.15 & $0.64 * * *$ & 0.34 & 0.23 & 0.14 \\
\hline & $(0.12)$ & $(0.15)$ & $(0.19)$ & $(0.19)$ & $(0.23)$ & $(0.28)$ & $(0.19)$ \\
\hline \multirow[t]{2}{*}{$\$ 100,000-\$ 119,999$} & $0.32 * *$ & 0.070 & 0.010 & $0.47 * *$ & 0.15 & -0.12 & 0.21 \\
\hline & $(0.12)$ & $(0.15)$ & $(0.20)$ & $(0.21)$ & $(0.25)$ & $(0.30)$ & $(0.19)$ \\
\hline \multirow[t]{2}{*}{$\$ 120,000-\$ 149,999$} & $0.45 * * *$ & 0.19 & 0.11 & $0.61 * * *$ & 0.27 & 0.34 & 0.27 \\
\hline & $(0.13)$ & $(0.16)$ & $(0.20)$ & $(0.21)$ & $(0.25)$ & $(0.31)$ & $(0.20)$ \\
\hline
\end{tabular}




\section{$\$ 150,000$ or greater}

Prefer not to say

Employment status (ref. $=$ full-time) Part-time

Temporarily laid off

Unemployed

Retired

Permanently disabled

Homemaker

Student

Other

Union membership (ref. $=$ never)

Current

Former

Pct. non-Hispanic White '10-14 (county-level)

Logged population density '10-14 (county-level)

Time at current residence (ref. = less than 1 year) 1-2 years

3-4 years

5 or more years

Current city residence length in years

State of residence $($ ref. $=$ Alabama, Colorado for swing states $)$

\begin{tabular}{|c|c|c|c|}
\hline $0.33^{* *}$ & 0.0040 & -0.21 & $0.65^{* * *}$ \\
\hline$(0.13)$ & $(0.16)$ & $(0.21)$ & $(0.23)$ \\
\hline $0.22 *$ & -0.12 & -0.17 & 0.27 \\
\hline (0.11) & $(0.14)$ & $(0.18)$ & $(0.18)$ \\
\hline 0.053 & 0.066 & 0.054 & 0.057 \\
\hline$(0.061)$ & $(0.071)$ & $(0.091)$ & $(0.100)$ \\
\hline-0.16 & -0.30 & -0.27 & -0.19 \\
\hline$(0.25)$ & $(0.29)$ & $(0.37)$ & $(0.44)$ \\
\hline$-0.15^{*}$ & -0.027 & -0.16 & 0.076 \\
\hline$(0.089)$ & $(0.11)$ & $(0.14)$ & $(0.15)$ \\
\hline 0.0048 & 0.0079 & -0.032 & 0.10 \\
\hline$(0.058)$ & $(0.067)$ & $(0.087)$ & $(0.095)$ \\
\hline-0.11 & -0.047 & $-0.23 * *$ & -0.12 \\
\hline$(0.075)$ & $(0.092)$ & $(0.12)$ & $(0.12)$ \\
\hline$-0.27 * * *$ & $-0.27 * * *$ & $-0.33 * * *$ & -0.085 \\
\hline$(0.068)$ & $(0.082)$ & $(0.11)$ & $(0.11)$ \\
\hline $0.30^{* *}$ & -0.073 & -0.22 & 0.14 \\
\hline$(0.13)$ & $(0.14)$ & $(0.18)$ & $(0.21)$ \\
\hline-0.11 & -0.13 & -0.034 & -0.25 \\
\hline$(0.13)$ & $(0.16)$ & $(0.21)$ & $(0.24)$ \\
\hline 0.064 & -0.069 & -0.025 & 0.13 \\
\hline$(0.072)$ & $(0.080)$ & $(0.100)$ & $(0.13)$ \\
\hline 0.015 & -0.024 & -0.025 & -0.092 \\
\hline$(0.047)$ & $(0.053)$ & $(0.069)$ & $(0.075)$ \\
\hline$-0.0046^{* *}$ & $-0.0051^{* *}$ & -0.0013 & -0.0029 \\
\hline$(0.0020)$ & $(0.0023)$ & $(0.0030)$ & $(0.0034)$ \\
\hline$-0.044 * *$ & $-0.060 * * *$ & $-0.065^{* *}$ & $-0.081 * * *$ \\
\hline$(0.017)$ & $(0.020)$ & $(0.026)$ & $(0.031)$ \\
\hline-0.13 & $-0.29 * * *$ & $-0.25 * *$ & -0.18 \\
\hline$(0.080)$ & $(0.094)$ & $(0.12)$ & $(0.13)$ \\
\hline 0.034 & -0.13 & -0.18 & 0.10 \\
\hline$(0.078)$ & $(0.092)$ & $(0.12)$ & $(0.13)$ \\
\hline 0.082 & -0.10 & $-0.19^{*}$ & 0.14 \\
\hline (0.069) & $(0.082)$ & $(0.10)$ & $(0.11)$ \\
\hline 0.00095 & 0.0011 & -0.0012 & -0.00057 \\
\hline$(0.0012)$ & $(0.0015)$ & $(0.0018)$ & $(0.0021)$ \\
\hline
\end{tabular}

0.32
$(0.26)$
-0.076
$(0.22)$

0.097
$(0.11)$
-0.089
$(0.52)$
0.13
$(0.17)$
0.17
$(0.11)$
-0.047
$(0.14)$
-0.042
$(0.13)$
-0.24
$(0.24)$
-0.11
$(0.28)$

0.060
$(0.14)$
-0.13
$(0.085)$
-0.0021
$0.0038)$
$-0.12 * * *$
$(0.035)$
-0.25
$(0.15)$
0.029
$(0.15)$
0.000039
$(0.13)$
0.00031
$(0.0024)$




\begin{tabular}{|c|c|c|c|c|c|c|c|}
\hline Arizona & $\begin{array}{c}0.17 \\
(0.19)\end{array}$ & $\begin{array}{l}-0.019 \\
(0.24)\end{array}$ & $\begin{array}{l}-0.17 \\
(0.33)\end{array}$ & & & & $\begin{array}{c}0.55^{* * *} \\
(0.19)\end{array}$ \\
\hline \multirow[t]{2}{*}{ Arkansas } & -0.17 & -0.22 & $-0.73^{*}$ & & & & -0.20 \\
\hline & $(0.23)$ & $(0.29)$ & $(0.40)$ & & & & $(0.24)$ \\
\hline \multirow{2}{*}{ California } & 0.045 & -0.23 & -0.035 & & & & \\
\hline & $(0.18)$ & $(0.22)$ & $(0.31)$ & & & & \\
\hline \multirow[t]{2}{*}{ Colorado } & 0.13 & -0.32 & -0.44 & & & & 0.25 \\
\hline & $(0.22)$ & $(0.26)$ & $(0.35)$ & & & & $(0.26)$ \\
\hline \multirow[t]{2}{*}{ Connecticut } & 0.24 & 0.043 & -0.086 & & & & 0.44 \\
\hline & $(0.23)$ & $(0.28)$ & $(0.37)$ & & & & $(0.28)$ \\
\hline \multirow[t]{2}{*}{ Delaware } & 0.49 & 0.19 & 0.042 & & & & 0.45 \\
\hline & $(0.30)$ & $(0.35)$ & $(0.45)$ & & & & $(0.43)$ \\
\hline \multirow[t]{2}{*}{ District of Columbia } & -0.93 & $-1.39 * *$ & -0.62 & & & & -0.094 \\
\hline & $(0.59)$ & $(0.61)$ & $(0.78)$ & & & & $(0.93)$ \\
\hline \multirow[t]{2}{*}{ Florida } & $0.32 *$ & 0.056 & -0.25 & 0.25 & $0.47^{* * *}$ & 0.30 & $0.39 * *$ \\
\hline & $(0.17)$ & $(0.22)$ & $(0.30)$ & $(0.16)$ & $(0.18)$ & $(0.23)$ & $(0.17)$ \\
\hline \multirow[t]{2}{*}{ Georgia } & $0.41 * *$ & 0.28 & 0.22 & & & & -0.0064 \\
\hline & $(0.19)$ & $(0.24)$ & $(0.33)$ & & & & $(0.18)$ \\
\hline \multirow{2}{*}{ Hawaii } & 0.41 & 0.036 & 0.31 & & & & 0.21 \\
\hline & $(0.43)$ & $(0.50)$ & $(0.65)$ & & & & $(0.54)$ \\
\hline \multirow[t]{2}{*}{ Idaho } & $-0.51^{*}$ & $-1.06^{* * *}$ & -0.22 & & & & -0.18 \\
\hline & $(0.27)$ & $(0.31)$ & $(0.45)$ & & & & $(0.29)$ \\
\hline \multirow[t]{2}{*}{ Illinois } & 0.089 & -0.17 & -0.29 & & & & -0.026 \\
\hline & $(0.19)$ & $(0.23)$ & $(0.32)$ & & & & $(0.19)$ \\
\hline \multirow[t]{2}{*}{ Indiana } & 0.21 & 0.0077 & -0.17 & & & & 0.28 \\
\hline & $(0.19)$ & $(0.24)$ & $(0.33)$ & & & & $(0.20)$ \\
\hline \multirow{2}{*}{ Iowa } & -0.016 & $-0.50^{*}$ & -0.45 & -0.21 & -0.30 & -0.15 & $-0.85 * * *$ \\
\hline & $(0.23)$ & $(0.27)$ & $(0.37)$ & $(0.22)$ & $(0.24)$ & $(0.31)$ & $(0.29)$ \\
\hline \multirow[t]{2}{*}{ Kansas } & 0.14 & -0.30 & -0.25 & & & & -0.48 \\
\hline & $(0.24)$ & $(0.29)$ & $(0.39)$ & & & & $(0.30)$ \\
\hline \multirow[t]{2}{*}{ Kentucky } & 0.22 & -0.13 & -0.52 & & & & -0.11 \\
\hline & $(0.21)$ & $(0.25)$ & $(0.34)$ & & & & $(0.23)$ \\
\hline \multirow[t]{2}{*}{ Louisiana } & 0.29 & 0.028 & -0.032 & & & & 0.38 \\
\hline & $(0.23)$ & $(0.29)$ & $(0.40)$ & & & & $(0.24)$ \\
\hline \multirow[t]{2}{*}{ Maine } & 0.10 & -0.26 & -0.21 & & & & -0.25 \\
\hline & $(0.27)$ & $(0.32)$ & $(0.42)$ & & & & $(0.41)$ \\
\hline \multirow[t]{2}{*}{ Maryland } & 0.015 & -0.040 & 0.19 & & & & 0.24 \\
\hline & $(0.21)$ & $(0.26)$ & $(0.35)$ & & & & $(0.23)$ \\
\hline \multirow[t]{2}{*}{ Massachusetts } & -0.22 & $-0.52 * *$ & $-0.61 *$ & & & & 0.12 \\
\hline & $(0.21)$ & $(0.25)$ & $(0.34)$ & & & & $(0.23)$ \\
\hline
\end{tabular}




\begin{tabular}{|c|c|c|c|c|c|c|c|}
\hline Michigan & $\begin{array}{c}0.25 \\
(0.19)\end{array}$ & $\begin{array}{l}0.031 \\
(0.23)\end{array}$ & $\begin{array}{l}-0.049 \\
(0.32)\end{array}$ & $\begin{array}{c}0.15 \\
(0.18)\end{array}$ & $\begin{array}{l}0.36^{*} \\
(0.19)\end{array}$ & $\begin{array}{c}0.39 \\
(0.25)\end{array}$ & $\begin{array}{l}-0.20 \\
(0.20)\end{array}$ \\
\hline Minnesota & $\begin{array}{c}0.27 \\
(021)\end{array}$ & $\begin{array}{l}-0.018 \\
(025)\end{array}$ & $\begin{array}{l}-0.40 \\
(0.35)\end{array}$ & $\begin{array}{c}0.12 \\
(020)\end{array}$ & $\begin{array}{c}0.26 \\
(022)\end{array}$ & $\begin{array}{c}-0.00045 \\
(028)\end{array}$ & $\begin{array}{l}-0.35 \\
(0.26)\end{array}$ \\
\hline Mississippi & $\begin{array}{c}(0.21) \\
-0.27 \\
(0.29)\end{array}$ & $\begin{array}{c}(0.25) \\
-0.18 \\
(0.38)\end{array}$ & $\begin{array}{l}(0.35) \\
-0.040 \\
(0.53)\end{array}$ & $(0.20)$ & $(0.22)$ & $(0.28)$ & $\begin{array}{c}(0.26) \\
0.35 \\
(0.29)\end{array}$ \\
\hline Missouri & $\begin{array}{c}0.10 \\
(0.20)\end{array}$ & $\begin{array}{l}-0.39 \\
(0.24)\end{array}$ & $\begin{array}{l}-0.41 \\
(0.33)\end{array}$ & & & & $\begin{array}{c}0.11 \\
(0.20)\end{array}$ \\
\hline Montana & $\begin{array}{c}0.38 \\
(0.33)\end{array}$ & $\begin{array}{l}-0.21 \\
(0.38)\end{array}$ & $\begin{array}{l}-0.15 \\
(0.50)\end{array}$ & & & & \\
\hline Nebraska & $\begin{array}{l}0.066 \\
(0.25)\end{array}$ & $\begin{array}{l}-0.15 \\
(0.31)\end{array}$ & $\begin{array}{l}-0.44 \\
(0.42)\end{array}$ & & & & \\
\hline Nevada & $\begin{array}{c}0.18 \\
(0.23)\end{array}$ & $\begin{array}{l}-0.087 \\
(0.28)\end{array}$ & $\begin{array}{l}-0.21 \\
(0.36)\end{array}$ & $\begin{array}{l}0.065 \\
(0.23)\end{array}$ & $\begin{array}{c}0.24 \\
(0.26)\end{array}$ & $\begin{array}{c}0.19 \\
(0.31)\end{array}$ & $\begin{array}{c}0.49^{*} \\
(0.28)\end{array}$ \\
\hline New Hampshire & $\begin{array}{l}-0.083 \\
(0.27)\end{array}$ & $\begin{array}{l}-0.37 \\
(0.31)\end{array}$ & $\begin{array}{c}-0.81 * * \\
(0.41)\end{array}$ & $\begin{array}{l}-0.26 \\
(0.26)\end{array}$ & $\begin{array}{l}-0.14 \\
(0.29)\end{array}$ & $\begin{array}{l}-0.49 \\
(0.36)\end{array}$ & $\begin{array}{l}-0.59^{*} \\
(0.30)\end{array}$ \\
\hline New Jersey & $\begin{array}{l}0.34^{*} \\
(0.19)\end{array}$ & $\begin{array}{c}0.23 \\
(0.24)\end{array}$ & $\begin{array}{c}0.23 \\
(0.32)\end{array}$ & & & & \\
\hline New Mexico & $\begin{array}{l}-0.34 \\
(0.31)\end{array}$ & $\begin{array}{c}-0.69^{* *} \\
(0.35)\end{array}$ & $\begin{array}{l}-0.57 \\
(0.48)\end{array}$ & & & & \\
\hline New York & $\begin{array}{l}0.39 * * \\
(0.18)\end{array}$ & $\begin{array}{c}0.30 \\
(0.23)\end{array}$ & $\begin{array}{c}0.25 \\
(0.31)\end{array}$ & & & & $\begin{array}{c}0.64 * * * \\
(0.20)\end{array}$ \\
\hline North Carolina & $\begin{array}{c}0.23 \\
(0.19)\end{array}$ & $\begin{array}{l}-0.032 \\
(0.23)\end{array}$ & $\begin{array}{l}-0.18 \\
(0.32)\end{array}$ & $\begin{array}{c}0.11 \\
(0.18)\end{array}$ & $\begin{array}{c}0.30 \\
(0.20)\end{array}$ & $\begin{array}{c}0.29 \\
(0.26)\end{array}$ & $\begin{array}{l}-0.13 \\
(0.18)\end{array}$ \\
\hline North Dakota & $\begin{array}{l}-0.59 \\
(0.37)\end{array}$ & $\begin{array}{c}-1.17^{* * *} \\
(0.42)\end{array}$ & $\begin{array}{c}-1.31 * * \\
(0.57)\end{array}$ & & & & $\begin{array}{c}0.24 \\
(0.49)\end{array}$ \\
\hline Ohio & $\begin{array}{c}0.25 \\
(0.19)\end{array}$ & $\begin{array}{l}0.0042 \\
(0.23)\end{array}$ & $\begin{array}{l}-0.29 \\
(0.31)\end{array}$ & $\begin{array}{c}0.15 \\
(0.17)\end{array}$ & $\begin{array}{l}0.35^{*} \\
(0.19)\end{array}$ & $\begin{array}{c}0.18 \\
(0.25)\end{array}$ & $\begin{array}{l}-0.26 \\
(0.19)\end{array}$ \\
\hline Oklahoma & $\begin{array}{l}-0.19 \\
(0.23)\end{array}$ & $\begin{array}{l}-0.44 \\
(0.28)\end{array}$ & $\begin{array}{c}-0.91 * * \\
(0.38)\end{array}$ & & & & $\begin{array}{l}-0.23 \\
(0.25)\end{array}$ \\
\hline Oregon & $\begin{array}{c}0.24 \\
(0.22)\end{array}$ & $\begin{array}{l}-0.10 \\
(0.26)\end{array}$ & $\begin{array}{l}-0.13 \\
(0.36)\end{array}$ & & & & \\
\hline Pennsylvania & $\begin{array}{l}0.30^{*} \\
(0.18)\end{array}$ & $\begin{array}{c}0.15 \\
(0.22)\end{array}$ & $\begin{array}{l}-0.099 \\
(0.31)\end{array}$ & $\begin{array}{c}0.20 \\
(0.17)\end{array}$ & $\begin{array}{c}0.49 * * * \\
(0.19)\end{array}$ & $\begin{array}{c}0.35 \\
(0.24)\end{array}$ & $\begin{array}{c}0.41^{* *} \\
(0.19)\end{array}$ \\
\hline Rhode Island & $\begin{array}{c}0.23 \\
(0.32)\end{array}$ & $\begin{array}{l}-0.017 \\
(0.37)\end{array}$ & $\begin{array}{l}0.0085 \\
(0.47)\end{array}$ & & & & $\begin{array}{l}1.02^{* *} \\
(0.42)\end{array}$ \\
\hline South Carolina & $\begin{array}{l}0.37^{*} \\
(0.21)\end{array}$ & $\begin{array}{c}0.44 \\
(0.27)\end{array}$ & $\begin{array}{c}0.57 \\
(0.37)\end{array}$ & & & & $\begin{array}{l}-0.12 \\
(0.21)\end{array}$ \\
\hline South Dakota & $\begin{array}{c}0.24 \\
(0.32)\end{array}$ & $\begin{array}{l}-0.023 \\
(0.39)\end{array}$ & $\begin{array}{l}0.0048 \\
(0.52)\end{array}$ & & & & \\
\hline
\end{tabular}




\begin{tabular}{|c|c|c|c|c|c|c|c|}
\hline Tennessee & $\begin{array}{l}0.085 \\
(0.20)\end{array}$ & $\begin{array}{l}-0.14 \\
(0.25)\end{array}$ & $\begin{array}{l}-0.37 \\
(0.34)\end{array}$ & & & & $\begin{array}{c}0.17 \\
(0.20)\end{array}$ \\
\hline Texas & $\begin{array}{l}0.0057 \\
(0.18)\end{array}$ & $\begin{array}{l}-0.030 \\
(0.22)\end{array}$ & $\begin{array}{l}-0.14 \\
(0.31)\end{array}$ & & & & $\begin{array}{c}-0.51^{* * *} \\
(0.17)\end{array}$ \\
\hline Utah & $\begin{array}{c}-1.07^{* * *} \\
(0.23)\end{array}$ & $\begin{array}{c}-1.63 * * * \\
(0.27)\end{array}$ & $\begin{array}{l}-0.77^{*} \\
(0.41)\end{array}$ & & & & $\begin{array}{l}-0.21 \\
(0.28)\end{array}$ \\
\hline Vermont & $\begin{array}{l}-0.15 \\
(0.39)\end{array}$ & $\begin{array}{l}-0.31 \\
(0.45)\end{array}$ & $\begin{array}{c}0.23 \\
(0.60)\end{array}$ & & & & $\begin{array}{l}-0.40 \\
(0.53)\end{array}$ \\
\hline Virginia & $\begin{array}{l}0.0099 \\
(0.19)\end{array}$ & $\begin{array}{l}-0.30 \\
(0.23)\end{array}$ & $\begin{array}{l}-0.35 \\
(0.32)\end{array}$ & $\begin{array}{l}-0.097 \\
(0.18)\end{array}$ & $\begin{array}{l}0.077 \\
(0.20)\end{array}$ & $\begin{array}{c}0.18 \\
(0.26)\end{array}$ & $\begin{array}{l}-0.18 \\
(0.19)\end{array}$ \\
\hline Washington & $\begin{array}{c}0.24 \\
(0.21)\end{array}$ & $\begin{array}{l}-0.13 \\
(0.25)\end{array}$ & $\begin{array}{l}0.058 \\
(0.34)\end{array}$ & & & & \\
\hline West Virginia & $\begin{array}{l}-0.16 \\
(0.24)\end{array}$ & $\begin{array}{l}-0.38 \\
(0.30)\end{array}$ & $\begin{array}{l}-0.68^{*} \\
(0.41)\end{array}$ & & & & \\
\hline Wisconsin & $\begin{array}{c}0.13 \\
(0.20)\end{array}$ & $\begin{array}{l}-0.028 \\
(0.25)\end{array}$ & $\begin{array}{l}-0.078 \\
(0.34)\end{array}$ & $\begin{array}{l}0.0051 \\
(0.19)\end{array}$ & $\begin{array}{c}0.26 \\
(0.21)\end{array}$ & $\begin{array}{c}0.30 \\
(0.27)\end{array}$ & $\begin{array}{l}-0.23 \\
(0.22)\end{array}$ \\
\hline Wyoming & $\begin{array}{c}-1.09 * * \\
(0.44)\end{array}$ & $\begin{array}{c}-1.27 * * \\
(0.53)\end{array}$ & $\begin{array}{c}-1.55^{* *} \\
(0.78)\end{array}$ & & & & $\begin{array}{c}0.27 \\
(0.50)\end{array}$ \\
\hline \multicolumn{8}{|c|}{ National economy in the past year (ref. = gotten much better) } \\
\hline Gotten better & $\begin{array}{c}-0.38^{* * *} \\
(0.13)\end{array}$ & $\begin{array}{c}-0.40^{* * *} \\
(0.15)\end{array}$ & $\begin{array}{l}-0.29^{*} \\
(0.16)\end{array}$ & $\begin{array}{c}0.000075 \\
(0.23)\end{array}$ & $\begin{array}{c}-0.059 \\
(0.25)\end{array}$ & $\begin{array}{l}-0.066 \\
(0.27)\end{array}$ & $\begin{array}{c}-1.12^{* * * *} \\
(0.28)\end{array}$ \\
\hline Stayed about the same & $\begin{array}{c}0.56^{* * *} \\
(0.13)\end{array}$ & $\begin{array}{c}0.52^{* * *} \\
(0.15)\end{array}$ & $\begin{array}{c}0.72 * * * \\
(0.17)\end{array}$ & $\begin{array}{c}1.04 * * * \\
(0.23)\end{array}$ & $\begin{array}{c}0.98^{* * *} \\
(0.25)\end{array}$ & $\begin{array}{c}1.07^{* * *} \\
(0.27)\end{array}$ & $\begin{array}{c}-0.74^{* * * *} \\
(0.28)\end{array}$ \\
\hline Gotten worse & $\begin{array}{c}1.25^{* * *} \\
(0.14)\end{array}$ & $\begin{array}{c}1.37^{* * * *} \\
(0.15)\end{array}$ & $\begin{array}{c}1.76^{* * * *} \\
(0.17)\end{array}$ & $\begin{array}{c}1.82^{* * *} \\
(0.24)\end{array}$ & $\begin{array}{c}1.90^{* * *} \\
(0.26)\end{array}$ & $\begin{array}{c}2.21^{* * *} \\
(0.28)\end{array}$ & $\begin{array}{l}-0.28 \\
(0.28)\end{array}$ \\
\hline Gotten much worse & $\begin{array}{c}1.51^{* * *} \\
(0.15)\end{array}$ & $\begin{array}{c}1.80^{* * *} \\
(0.17)\end{array}$ & $\begin{array}{c}2.22 * * * \\
(0.20)\end{array}$ & $\begin{array}{c}2.19 * * * \\
(0.25)\end{array}$ & $\begin{array}{c}2.35^{* * *} \\
(0.28)\end{array}$ & $\begin{array}{c}2.62 * * * \\
(0.32)\end{array}$ & $\begin{array}{c}0.13 \\
(0.28)\end{array}$ \\
\hline Not sure & $\begin{array}{l}0.29^{*} \\
(0.17)\end{array}$ & $\begin{array}{c}0.29 \\
(0.19)\end{array}$ & $\begin{array}{c}0.64^{* * * *} \\
(0.23)\end{array}$ & $\begin{array}{c}0.89 * * * \\
(0.29)\end{array}$ & $\begin{array}{c}0.84^{* * * *} \\
(0.32)\end{array}$ & $\begin{array}{c}1.12^{* * *} \\
(0.36)\end{array}$ & $\begin{array}{l}-0.61^{*} \\
(0.35)\end{array}$ \\
\hline \multicolumn{8}{|c|}{ Household income in the past four years (ref. = increased a lot) } \\
\hline Increased somewhat & $\begin{array}{l}-0.033 \\
(0.094)\end{array}$ & $\begin{array}{c}-0.0063 \\
(0.10)\end{array}$ & $\begin{array}{l}-0.10 \\
(0.13)\end{array}$ & $\begin{array}{l}-0.088 \\
(0.16)\end{array}$ & $\begin{array}{l}0.028 \\
(0.17)\end{array}$ & $\begin{array}{c}-0.0033 \\
(0.21)\end{array}$ & $\begin{array}{l}0.31 * \\
(0.17)\end{array}$ \\
\hline Stayed about the same & $\begin{array}{c}0.17^{*} \\
(0.096)\end{array}$ & $\begin{array}{l}0.18^{*} \\
(0.11)\end{array}$ & $\begin{array}{l}0.014 \\
(0.13)\end{array}$ & $\begin{array}{c}0.14 \\
(0.16)\end{array}$ & $\begin{array}{c}0.22 \\
(0.18)\end{array}$ & $\begin{array}{c}0.17 \\
(0.21)\end{array}$ & $\begin{array}{l}0.37 * * \\
(0.17)\end{array}$ \\
\hline Decreased somewhat & $\begin{array}{c}0.28 * * * \\
(0.10)\end{array}$ & $\begin{array}{c}0.32 * * * \\
(0.11)\end{array}$ & $\begin{array}{c}0.16 \\
(0.14)\end{array}$ & $\begin{array}{c}0.13 \\
(0.17)\end{array}$ & $\begin{array}{c}0.23 \\
(0.19)\end{array}$ & $\begin{array}{c}0.19 \\
(0.23)\end{array}$ & $\begin{array}{l}0.33^{*} \\
(0.17)\end{array}$ \\
\hline Decreased a lot & $\begin{array}{l}0.24^{* *} \\
(0.11)\end{array}$ & $\begin{array}{l}0.24^{*} \\
(0.13)\end{array}$ & $\begin{array}{c}0.15 \\
(0.16)\end{array}$ & $\begin{array}{c}0.21 \\
(0.19)\end{array}$ & $\begin{array}{c}0.27 \\
(0.21)\end{array}$ & $\begin{array}{c}0.25 \\
(0.25)\end{array}$ & $\begin{array}{c}0.25 \\
(0.18)\end{array}$ \\
\hline \multicolumn{8}{|c|}{ National economy in the next year will (ref. = get much better) } \\
\hline Get somewhat better & $-0.61 * * *$ & $-0.69 * * *$ & $-0.52 * * *$ & $-0.88 * * *$ & $-0.89 * * *$ & $-0.70 * * *$ & $-0.93 * * *$ \\
\hline
\end{tabular}




\begin{tabular}{|c|c|c|c|c|c|c|c|}
\hline & $(0.13)$ & $(0.14)$ & $(0.16)$ & $(0.21)$ & $(0.23)$ & $(0.25)$ & $(0.25)$ \\
\hline Stay about the same & $\begin{array}{c}-0.96^{* * *} \\
(0.13)\end{array}$ & $\begin{array}{c}-1.05 * * * \\
(0.15)\end{array}$ & $\begin{array}{c}-0.65^{* * *} \\
(0.16)\end{array}$ & $\begin{array}{c}-1.09 * * * \\
(0.21)\end{array}$ & $\begin{array}{c}-1.15^{* * *} \\
(0.23)\end{array}$ & $\begin{array}{c}-0.79 * * * \\
(0.26)\end{array}$ & $\begin{array}{c}-1.46^{* * * *} \\
(0.25)\end{array}$ \\
\hline Get somewhat worse & $\begin{array}{c}-0.94 * * * \\
(0.13)\end{array}$ & $\begin{array}{c}-1.02 * * * \\
(0.15)\end{array}$ & $\begin{array}{c}-0.35^{* *} \\
(0.17)\end{array}$ & $\begin{array}{c}-1.04 * * * \\
(0.21)\end{array}$ & $\begin{array}{c}-1.06^{* * *} \\
(0.24)\end{array}$ & $\begin{array}{l}-0.43 \\
(0.27)\end{array}$ & $\begin{array}{c}-1.66^{* * * *} \\
(0.25)\end{array}$ \\
\hline Get much worse & $\begin{array}{c}-1.29 * * * \\
(0.14)\end{array}$ & $\begin{array}{c}-1.51 * * * \\
(0.16)\end{array}$ & $\begin{array}{c}-0.55^{* * *} \\
(0.20)\end{array}$ & $\begin{array}{c}-1.60 * * * \\
(0.23)\end{array}$ & $\begin{array}{c}-1.79 * * * \\
(0.26)\end{array}$ & $\begin{array}{c}-0.94 * * * \\
(0.31)\end{array}$ & $\begin{array}{c}-1.72 * * * \\
(0.26)\end{array}$ \\
\hline Not sure & $\begin{array}{c}-0.55^{* * *} \\
(0.13)\end{array}$ & $\begin{array}{c}-0.64 * * * \\
(0.15)\end{array}$ & $\begin{array}{l}-0.27 \\
(0.17)\end{array}$ & $\begin{array}{c}-0.66^{* * *} \\
(0.21)\end{array}$ & $\begin{array}{c}-0.78^{* * *} \\
(0.24)\end{array}$ & $\begin{array}{l}-0.41 \\
(0.27)\end{array}$ & $\begin{array}{c}-1.41^{* * * *} \\
(0.25)\end{array}$ \\
\hline \multicolumn{8}{|c|}{ Political ideology (ref. = very liberal) } \\
\hline Liberal & $\begin{array}{c}0.36 * * * \\
(0.13)\end{array}$ & $\begin{array}{c}0.33^{* *} \\
(0.14)\end{array}$ & $\begin{array}{c}0.32 * * \\
(0.15)\end{array}$ & $\begin{array}{c}0.22 \\
(0.21)\end{array}$ & $\begin{array}{c}0.19 \\
(0.22)\end{array}$ & $\begin{array}{c}0.14 \\
(0.24)\end{array}$ & $\begin{array}{l}-0.14 \\
(0.34)\end{array}$ \\
\hline Moderate & $\begin{array}{c}1.16^{* * * *} \\
(0.12)\end{array}$ & $\begin{array}{c}1.14 * * * \\
(0.13)\end{array}$ & $\begin{array}{c}1.22 * * * \\
(0.14)\end{array}$ & $\begin{array}{c}1.09^{* * * *} \\
(0.19)\end{array}$ & $\begin{array}{c}1.09^{* * *} \\
(0.20)\end{array}$ & $\begin{array}{c}1.11^{* * *} \\
(0.22)\end{array}$ & $\begin{array}{l}-0.21 \\
(0.31)\end{array}$ \\
\hline Conservative & $\begin{array}{c}1.98 * * * \\
(0.12)\end{array}$ & $\begin{array}{c}2.09^{* * *} \\
(0.13)\end{array}$ & $\begin{array}{c}2.42 * * * \\
(0.15)\end{array}$ & $\begin{array}{c}1.87^{* * * *} \\
(0.19)\end{array}$ & $\begin{array}{c}1.97 * * * \\
(0.21)\end{array}$ & $\begin{array}{c}2.17^{* * *} \\
(0.23)\end{array}$ & $\begin{array}{l}-0.36 \\
(0.32)\end{array}$ \\
\hline Very conservative & $\begin{array}{c}1.95 * * * \\
(0.13)\end{array}$ & $\begin{array}{c}2.12^{* * * *} \\
(0.15)\end{array}$ & $\begin{array}{c}2.91 * * * \\
(0.19)\end{array}$ & $\begin{array}{c}2.05^{* * * *} \\
(0.21)\end{array}$ & $\begin{array}{c}2.22 * * * \\
(0.24)\end{array}$ & $\begin{array}{c}2.76^{* * *} \\
(0.30)\end{array}$ & $\begin{array}{c}-1.00^{* * * *} \\
(0.32)\end{array}$ \\
\hline Not sure & $\begin{array}{c}0.54^{* * *} \\
(0.14)\end{array}$ & $\begin{array}{c}1.11^{* * *} \\
(0.15)\end{array}$ & $\begin{array}{c}1.25^{* * *} \\
(0.17)\end{array}$ & $\begin{array}{c}0.33 \\
(0.21)\end{array}$ & $\begin{array}{c}1.01 * * * \\
(0.24)\end{array}$ & $\begin{array}{c}1.07 * * * \\
(0.27)\end{array}$ & $\begin{array}{l}0.030 \\
(0.36)\end{array}$ \\
\hline Constant & $\begin{array}{c}5.19 \\
(3.77)\end{array}$ & $\begin{array}{c}3.12 \\
(4.36)\end{array}$ & $\begin{array}{c}-14.5^{* * *} \\
(5.59)\end{array}$ & $\begin{array}{l}1.78 \\
(6.26)\end{array}$ & $\begin{array}{l}-0.86 \\
(7.19)\end{array}$ & $\begin{array}{l}-15.4^{*} \\
(8.83)\end{array}$ & $\begin{array}{c}14.6^{* * *} \\
(5.17)\end{array}$ \\
\hline Observations & 36,911 & 32,448 & 29,462 & 14,022 & 12,381 & 11,380 & 10,216 \\
\hline
\end{tabular}

Standard errors in parentheses

$* * * \mathrm{p}<0.01, * * \mathrm{p}<0.05, * \mathrm{p}<0.1$

Sources: Authors' calculations from the Cooperative Congressional Election Study, 2016, the American Community Survey, 2010-2014, and Election Atlas.

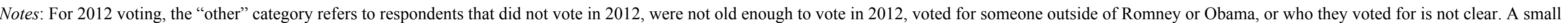
number of respondents that were not old enough to vote in 2012 claim to have voted for Obama or Romney, so we code them as having voted for one of these candidates in order to capture their preference. 